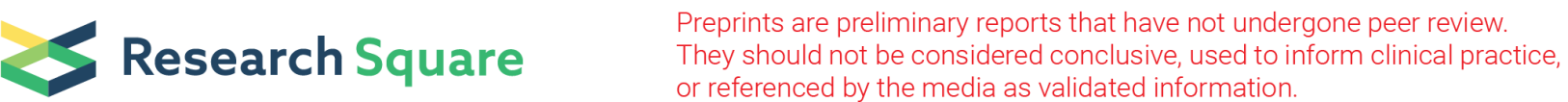

\section{Protocol to Evaluate the Implementation of an Enterprise-Wide Initiative to Increase Access to Lung Cancer Screening in the Veterans Health Administration}

Jennifer A. Lewis ( $\square$ jennifer.a.lewis@vumc.org )

VA Tennessee Valley Healthcare System Nashville Campus: VA Tennessee Valley Healthcare System https://orcid.org/0000-0002-4234-1765

Lucy B. Spalluto

VA Tennessee Valley Healthcare System Nashville Campus: VA Tennessee Valley Healthcare System

Claudia I. Henschke

Icahn School of Medicine at Mount Sinai

David F. Yankelevitz

Icahn School of Medicine at Mount Sinai

Samuel M. Aguayo

Phoenix VA Health Care System

Providencia Morales

Phoenix VA Health Care System

Rick Avila

Paraxial LLC

Carolyn M. Audet

Vanderbilt University School of Medicine

Beth Prusaczyk

Washington University School of Medicine

Christopher J. Lindsell

Vanderbilt University School of Medicine

Carol Callaway-Lane

VA Tennessee Valley Healthcare System

Robert S. Dittus

Vanderbilt University Medical Center

Timothy J. Vogus

Vanderbilt University

Pierre P. Massion

Vanderbilt University Medical Center

Heather M. Limper 
Vanderbilt University Medical Center

\section{Sunil Kripalani}

Vanderbilt University Medical Center

Drew Moghanaki

Atlanta VA Medical Center

Christianne L. Roumie

Vanderbilt University Medical Center

\section{Study protocol}

Keywords: lung cancer screening, program evaluation, Veterans, implementation science

Posted Date: September 22nd, 2020

DOI: https://doi.org/10.21203/rs.3.rs-76126/v1

License: (c) (i) This work is licensed under a Creative Commons Attribution 4.0 International License.

Read Full License

Version of Record: A version of this preprint was published at Clinical Imaging on May 1st, 2021. See the published version at https://doi.org/10.1016/j.clinimag.2020.11.059. 


\section{Abstract \\ Background}

The Veterans Affairs Partnership to increase Access to Lung Screening (VA-PALS) is an enterprise-wide initiative to implement high quality lung cancer screening programs at VA medical centers (VAMCs). VAPALS will be using implementation strategies that include program navigators to coordinate screening activities, trainings for navigators and radiologists, an open-source software management system, tools to standardize low-dose computed tomography (LDCT) image quality, and access to a support network. Individual VAMCs can utilize strategies according to their local contextual factors. In this protocol, we describe the planned program evaluation for the initial 10 VAMCs participating in VA-PALS.

\section{Methods}

The implementation of programs will be evaluated using the Consolidated Framework for Implementation Research to ensure broad contextual guidance. Program evaluation measures have been developed using the Reach, Effectiveness, Adoption, Implementation and Maintenance framework. Adaptations of screening processes will be assessed every six months using the Framework for Reporting Adaptations and Modifications to Evidence Based Interventions. Measures collected will reflect the inner setting at each VAMC, estimate and describe the population reached, adoption by providers, implementation of the programs, report patient clinical outcomes and maintenance of screening programs. Analyses will primarily use descriptive statistics with means, medians, and frequencies. Outcomes will be compared over time and among VA-PALS VAMCs and non-VA-PALS VAMCs in interrupted time series analyses. Assessment of contextual factors and the relationship between predictors, such as organizational readiness and improved implementation, will be evaluated. Adaptations of processes to overcome barriers will be identified and evaluated for association with implementation.

\section{Conclusion}

This theory-based protocol will evaluate the implementation of lung cancer screening programs across the Veterans Health Administration (VHA) using scientific frameworks. The findings will inform plans to expand the VA-PALS initiative beyond the original sites and can guide implementation of lung cancer screening programs more broadly within and outside VHA.

\section{Contributions To The Literature}

- The VA Partnership to increase Access to Lung Screening (VA-PALS) is an initiative designed to implement lung cancer screening programs at VA medical centers (VAMCs) using the following strategies: hiring a program navigator who coordinates screening activities, trainings for navigators 
and radiologists, a software management system, low-dose CT image standardization tools, and an expert support network.

- Several implementation science frameworks (CFIR, RE-AIM, FRAME) inform the design of the program evaluation. Implementation measures will include evaluation of the inner setting through interviews and assessment of organizational readiness, estimation of the population reached, adoption, implementation of the program, clinical and process outcomes, and long-term maintenance of lung cancer screening programs.

- Measurement of contextual factors as well as assessment of workflow processes and adaptations to overcome barriers may generate new knowledge that impacts implementation of lung cancer screening programs more broadly.

\section{Background}

In 2020 , lung cancer is expected to cause 135,720 deaths in the United States, which is more than colorectal, breast and prostate cancer deaths combined. ${ }^{1}$ Most patients $(74 \%)$ are diagnosed with lung cancer at advanced stages when there is less chance for curative treatment, which contributes to its high mortality. ${ }^{1}$ Stimulated by the results of the Early Lung Cancer Action Project (ELCAP), ${ }^{2-4}$ two large U.S. (the National Lung Screening Trial [NLST]) and European (the Dutch-Belgian Lung Cancer Screening Trial [NELSON]) multi-center, randomized-controlled trials demonstrated that early detection with low-dose computed tomography (LDCT) decreased lung cancer-specific mortality in high-risk individuals. 5,6 Following the results of these trials, many professional organizations developed guideline recommendations ${ }^{7-11}$ and the United States Preventive Services Task Force (USPSTF) issued a grade B recommendation for annual lung cancer screening with LDCT in the high-risk population. ${ }^{12}$ The USPSTF defines high-risk individuals as being between the age of 55 to 80 , current or former smokers, who have quit within the past 15 years, and have a minimum of a 30 pack-year history of cigarette smoking. ${ }^{12}$ Under the Affordable Care Act, LDCT screening is considered a preventive care service with coverage by most private insurance plans. ${ }^{12}$ In 2015, the Centers for Medicare \& Medicaid Services (CMS) added coverage for LDCT screening high-risk individuals ${ }^{13}$ and integrated smoking cessation as part of the screening program. In fact, screening has created a "teachable moment" that can change smoking behavior. ${ }^{14-21}$ The newly proposed USPSTF guidelines have suggested even broader entry criteria as does the European Union. ${ }^{11,22}$

The Veteran population has higher cigarette smoking rates than non-Veterans ${ }^{23,24}$ and lung cancer screening programs may be particularly beneficial in this population. The Veterans Health Administration (VHA) has begun to implement lung cancer screening programs that combine early detection with primary prevention (tobacco cessation). ${ }^{25-27}$ Between 2013 and 2015, VHA conducted the Lung Cancer Screening Clinical Demonstration Project at eight Veterans Affairs Medical Centers (VAMCs). ${ }^{28}$ After two years, participating VAMCs screened approximately 2,100 Veterans and identified 31 lung cancers, of which $64.5 \%$ were stage I. ${ }^{26}$ Significant variability in implementation was observed between sites, 
especially around the processes of identifying eligible Veterans, identifying the staff who engaged in shared decision-making, assigning responsibilities to coordinators, trainings for primary care and radiology, communicating screening results to patients, and assigning responsibility for follow up of abnormalities not related to lung cancer (emphysema, coronary artery disease, etc.). ${ }^{26}$ This initial evaluation by VHA was limited in its exploration of local contextual factors as well as associations between processes of care and adaptations over time. ${ }^{26}$

Lung cancer screening utilization in the United States is exceedingly low $(<14 \%),{ }^{29-31}$ including in VHA. ${ }^{32}$ This makes strategies to improve implementation critically important. Building upon VHA's Lung Cancer Screening Clinical Demonstration Project, the Veterans Affairs Partnership to increase Access to Lung Screening (VA-PALS) initiative was developed by its leadership team with the overall vision to implement lung cancer screening programs that improve Veteran outcomes through evidence-based and high-quality early lung cancer detection and primary prevention. ${ }^{33-35}$ VA-PALS was designed to consider the unique local environments, distinct culture, and varying levels of resources across VAMCs in disparate geographic locations (Fig. 1). The overarching aims of VA-PALS are to:

1) Implement evidence-based lung cancer screening programs by developing and deploying the opensource VAPALS-ELCAP Management System adapted for the needs of the VA to track Veterans from the initial contact through a long-term screening and diagnostic process that could eventually lead to lung cancer diagnoses, providing training of navigators, radiologists and other team members, assessing screening protocol adherence, continuous quality assurance assessment, and assessing outcomes at the 10 high-volume VAMCs.

2) Perform a formal evaluation of the 10 nascent lung cancer screening programs to measure the impact of increasing Veterans access to lung cancer screening, rates of early detection, and opportunity for mortality reduction.

Lung cancer screening implementation has not been rigorously studied using an implementation science theory-based approach. ${ }^{26,36}$ The purpose of this protocol to describe the scientific frameworks and protocol developed to inform and evaluate the implementation of lung cancer screening programs at VAMCs participating in VA-PALS (Fig. 1). VA-PALS lends itself as a unique opportunity to explore theorybased relationships between types of strategies (the navigators as a team-based strategy, the phantoms as an intervention characteristic-based strategy, and the software management system as a workflow processes-based strategy) and their effects on evaluation constructs (reach, effectiveness, adoption, implementation and maintenance) across multiple settings. In addition, we will also validate an organizational readiness measurement too ${ }^{34}$ in a national cohort of VHA employees, assess reach at multiple points along the screening process, explore barriers of rural Veterans for future outreach interventions, and will report adaptations in screening processes overtime in multiple programs. These data will likely generate new knowledge that will influence lung cancer screening program implementation more broadly within and outside the VHA. 


\section{Methods/design}

\section{Program Status}

This program evaluation was approved by VA Central Institutional Review Board (C-IRB E19-05) on September 23, 2019 and the VA Tennessee Valley Healthcare System Research \& Development Committee on November 21, 2019. The VA Organizational Assessment Subcommittee approved the study on October 1, 2019 and the VA Office of Labor and Management Relations (national union approval) approved the study on January 27, 2020. This report was approved by the VA Office of Rural Health on March 17, 2020.

Aim

The aim of this program evaluation is to develop and report lung cancer screening workflow and clinical outcome measures as well as contextual factors that influence implementation at sites participating in VA-PALS.

Implementation Strategies

Each VAMC participating in VA-PALS has a designated site champion and will receive the following: (1) a full-time lung cancer screening navigator (NP or PA) to support program development and coordinate screening-related care], (2) a comprehensive, open-source lung cancer screening management software system $^{33,35}$ (3) training for navigators and radiologists, (4) expert guidance to standardize screening protocol adherence and LDCT imaging quality, and (5) a support network led by experienced screening leaders.

Decisions regarding individual site's lung cancer screening program structure and workflow will be determined at the local level depending on the environment, resources available, and culture. As such, sites will be able to adapt their processes over time for different reasons (e.g., contextual pressures, leadership support, trial and error, etc.). These changes will be measured to enhance our understanding of how naturalistic implementation influences processes and the impact these changes may have on overcoming barriers.

\section{Logic Model (Figure 2)}

Inputs - People, Technology

People. VA-PALS will be overseen by an inter-professional leadership team of radiologists, a pulmonologist, a radiation oncologist, a screening navigator, and technology specialists at Atlanta VA Medical Center, Phoenix VA Health Care System, Early Lung and Cardiac Action Program at Mount Sinai Health System (MS-ELCAP), and Paraxial LLC who have expertise in lung cancer screening, treatment, research and healthcare computer science. ${ }^{35}$ The software team is comprised of software developers with experience in VA networks and informatics experts at MS-ELCAP. The VA-PALS program evaluation 
team includes health services researchers at VA Tennessee Valley Healthcare System Geriatric Research, Education and Clinical Center and Vanderbilt University Medical Center working together with the VAPALS leadership team and participating VAMCs. Participating VAMCs have or will have local teams that include a site champion, program director(s), screening program navigator, clinical providers, and software engineers.

Technology. The ELCAP Management System was designed to manage and organize lung cancer screening activities and has been in use since $1992 .{ }^{35}$ This software system has been used at 82 institutions in 10 countries and is a tool for navigators and radiologists to document, organize, and manage screening-related activities from the initial contact, screening follow up, evaluation of screening findings, and treatment of those diagnosed with lung cancer. ${ }^{2,4,35}$ This software also serves as a database for improvement initiatives. ${ }^{35}$ Other technological inputs include the CT scanners for screening examinations and small nodule phantoms of the CT scanning protocols for quality assurance. ${ }^{35}$

A phantom is a specially designed object that can be scanned by a CT scanner and provides the information about the performance of the CT scanner and scanning parameters which can be used to optimize images CT screening.

\section{Activities}

Support Network Activities. The leadership team will provide guidance and support for each VA-PALS program through planned activities and site monitoring. It will provide standardized training for all newly hired navigators and radiologists at each VA-PALS site along with a support network for the navigators, site champions and program directors through regular conference calls, national workshops, and an operational guide to lung cancer screening. The leadership team will also manage a website (www.vapals.org) to disseminate information and shared resources.

Quality Assurance Activities. The software team will translate the ELCAP Management System into the open source VAPALS-ELCAP Management System with guidance by the MS-ELCAP and leadership team. The software documents enrollment, screenings, follow-up, interventions, and treatment if diagnosed with lung cancer. It also provides management and quality assurance reports of screening protocol adherence and follow-up. This VAPALS-ELCAP Management System will then be integrated with the Veterans Health Information Systems and Technology Architecture (VistA) and the VHA's electronic health system electronic medical record, Computerized Patient Record System (CPRS). ${ }^{35}$ It will be tested and piloted at the Phoenix VAMC prior to dissemination to other participating VA-PALS VAMCs. The leadership team will provide each VAMC with an imaging phantom and the software team will provide feedback on their scanners' imaging quality. ${ }^{35}$ Phantoms will measure imaging sensitivity, dynamic range, contrast/detail detectability, and spatial resolution. This calibration tool will ensure proper parameters are being used for LDCT imaging to assure high-quality assessment of lung nodules. ${ }^{35}$ Local teams at each VAMC will use the VAPALS-ELCAP Management System and its quality assurance reports and the CT phantom 
assurance tools for program activities, adherence to the screening protocol, standardization of image parameters, and improvement initiatives.

Training Activities. Navigators will be trained by the MS-ELCAP and leadership teams on screening eligibility, shared decision-making, use of the management system, and coordination of screening-related activities. Radiologists will also be trained in the workflow and use of the VAPALS-ELCAP Management System.

Local Lung Cancer Screening Activities. Each site director will be tasked with hiring a lung cancer screening navigator (NP or PA), engaging their local stakeholders and administrators, developing a screening workflow, and educating local providers and staff about the program. Implementation of the lung cancer screening program will include the following activities: identify high-risk Veterans eligible for screening, perform shared decision-making, offer resources and/or treatment for smoking cessation, perform the LDCT scan, ensure structured radiology reporting, facilitate any indicated additional workup, and schedule either repeat annual LDCT or work up of findings suspicious for lung cancer as appropriate.

Data Collection Activities. The primary clinical and implementation outcome measures were developed by the VA-PALS leadership team, as part of their continued overall responsibility, together with the program evaluation team. The combined teams will work together to collect data from the management system, VHA's Clinical Data Warehouse (CDW), surveys, and interviews, will analyze results, and will share the data with the larger VA-PALS network. The program evaluation team will also participate in leadership and program meetings.

\section{Outcomes}

Short-term Outcomes: The short-term outcomes consist of VA-PALS's reach, adoption, effectiveness and implementation measures to be used within the first 24 months of the program, described in detail below and Table 1.

Long-term Outcomes: The long-term outcomes are the reach, implementation, effectiveness and maintenance measures to be used beyond 24 months since start of the program, described in detail below and in Table 1.

Target Population. The target population will include Veterans eligible for lung cancer screening, providers and staff involved in screening activities, and leadership at each VA-PALS site. Veterans eligible for lung cancer screening generally include those meeting the USPSTF criteria ${ }^{12}$; at least one site is using a more broad eligibility recommendation. ${ }^{37}$ Providers involved in screening activities will include primary care providers (physicians, advanced practice providers, and physicians-in-training), radiology providers, and navigators for each program. Staff involved will include primary care nurses, schedulers, clinical application coordinators (CACs) and radiology technicians/technologists. Leadership will include the local program leadership as well as service leaders within primary care, radiology, and specialty services and executive leadership team. 


\section{a. Implementation Framework}

Implementation of an evidence-based practice into healthcare delivery depends upon multiple internal and external contextual factors that ultimately influence the processes and outcomes of healthcare delivery. We selected the Consolidated Framework for Implementation Research (CFIR) to guide this program evaluation based on this framework's ability to provide structure to approaching the implementation of a complex, inter-professional program in a pragmatic manner. ${ }^{38}$ The CFIR explores the characteristics of an evidence-based practice, the inner and outer settings of where the evidence-based practice is deployed, the characteristics of the individuals interacting with the evidence-based practice, and the process of implementing the evidence-based practice. ${ }^{38}$ This mixed-methods program evaluation measures key elements of the five major CFIR domains: (1) characteristics of the evidence-based practice (image acquisition and CT standardization), (2) inner setting of each VA-PALS site (organizational readiness, resources) and (3) outer setting of VHA as a whole (policies), (4) the characteristics of individuals involved in the screening process (knowledge and beliefs, self-efficacy, and motivation), and the (5) process of implementation at each VA-PALS site (site process maps for implementation initially and adaptations over time) (Table 1). Thoroughly exploring each of these domains will inform future implementation strategies (Figure 3). ${ }^{38,39}$

\section{b. Evaluation Frameworks}

The Reach, Effectiveness, Adoption, Implementation, Maintenance (RE-AIM) framework was used to develop the program evaluation measures. ${ }^{40}$ This evaluation framework in the cancer screening setting ${ }^{41}$ and provides a comprehensive structure to assess real-world clinical programs. VA-PALS evaluation measures reflect the activities at each VAMC and clinical and process outcomes of each lung cancer screening program. For each site, the date of hire of the navigator will be considered the program start date. Evaluation of all measures of reach, effectiveness and maintenance will begin at the program start date and continue for the next 36 months, as defined by the navigator hire date. The VA-PALS leadership and evaluation teams will compare measures (i.e. number of Veterans reached, screening utilization, etc.) over time in VA-PALS and non-VA-PALS VAMCs in an interrupted time series analysis. Further, we will compare outcomes in months 1-24 to months 25-36 to evaluate for sustainability in VA-PALS and non-VAPALS VAMCs (Table 1).

\section{Reach}

The management system will capture descriptive information (e.g. age, smoking history, rural status), method of contact for screening (referral from primary care, specialty care or smoking cessation, outreach or self-referral). In order to have a consistent denominator of the eligible population across all sites, we will estimate the number of Veterans potentially eligible for lung cancer screening according to the USPSTF criteria. As used before, ${ }^{32}$ we will obtain counts of Veterans between the ages of 55 through 
80 seen at each VAMC each year. To calculate the percentage of age-appropriate Veterans with an eligible smoking history, we will multiply the age-appropriate population by $32 \%$ for each VAMC in each year; thirty-two percent was the percentage of age-appropriate Veterans who met the smoking eligibility criteria in the VHA's Clinical Lung Cancer Screening Demonstration Project. ${ }^{26}$ All of the components of the program's reach will be designed to capture the number of eligible Veterans at each stage of the process including Veterans approached for screening, eligibility as well as agreement and refusal both before and after the shared decision-making process, and unique Veterans completing initial screens (Figure 4).

\section{Effectiveness}

The effectiveness of the program will be evaluated using data acquired from VHA's Corporate Data Warehouse (CDW) and the VAPALS-ELCAP Management System. The measures chosen are reflective of the results of screening, the frequency and type of follow-up procedures performed, the number of cancers detected, type and stage of cancers, treatment received, other abnormal findings not suspicious of lung cancer and their follow up (e.g. cardiovascular disease, COPD, etc.), ${ }^{42}$ survival of screened Veterans, the number of smoking cessation quit attempts, ${ }^{14,16}$ the type of smoking cessation services provided, wait times for services provided, and overall experiences of those involved in the screening process (see Qualitative Section) (Table 1). We will compare different measures of effectiveness (number of LDCT scans, cancers diagnosed, stage at time of diagnosis, etc.) before and after implementation of the navigator and VAPALS-ELCAP Management System using an interrupted time series analysis. Other measures of effectiveness (wait times for services provided, workflow process maps, and overall experiences of those involved in the screening process) will also be tracked over time using the CDW, process mapping and surveys.

\section{Adoption}

Adoption will be assessed by describing the characteristics of the VAMC facilities participating in VAPALS. Organizational readiness for change will be measured using a validated survey tool to assess change valence, change commitment, and change efficacy ${ }^{34,43}$ to understand each VAMC's inner setting (Table 1). Organizational readiness for change is defined as the "extent to which organizational members are psychologically and behaviorally prepared to implement organizational change." ${ }^{44}$ Change valence is defined as the organization's members belief that pursuing change is beneficial and valuable to the organization. ${ }^{45}$ To describe the program implementation process, we will obtain interviews from sites and program leadership: (1) first date of posting the navigator position for hire by human resources, (2) first day navigator starts clinical work, (3) date of navigator training, (4) date of installation of the VAPALSELCAP Management System, and (5) dates of imaging phantom use and CT scanner standardization. The number of unique providers and types of providers (specialty; physician, advanced practice provider) referring to the program within the first 24 months since hiring of the coordinator will be captured in the CDW and VAPALS-ELCAP Management System. Finally, to describe adoption at the site-level, we will capture alignment with VHA priorities through in-depth interviews of program leadership at each site. 
Implementation

Implementation of lung cancer screening programs at the 10 VA-PALS sites will be captured via local program engagement to assess fidelity of the program (Table 1). Specifically, fidelity refers to the degree to which navigators, the management system, trainings, screening protocol adherence, and imaging phantoms are utilized at each site. Measures of fidelity will include the retention time of navigators, navigator workload, the number of radiologists who use the management system, the degree to which the navigators use the management system for screening related activities (approach/enroll Veterans, write notes, follow-up screening results, manage downstream follow-up, etc.), and the dates of phantom use and image standardization (Table 1). Measurement of each VAMC's inner setting will assess team characteristics, the processes involved in screening, and barriers and facilitators. We will assess how smoking cessation is incorporated into each local program (who performs it, type of services performed, when it is performed within screening), how shared decision-making discussions are performed, and how and when results are disseminated to patients and referring providers (see section on Process Maps below). These measures will be primarily obtained through interviews with sites and supplemented with data from the VAPALS-ELCAP Management System (Table 1).

\section{Maintenance}

We will measure the extent to which VA-PALS is sustainable over time using a combination of data collected from the VA-PALS-ELCAP Management System and interviews with local program leadership. Maintenance measurements will consist of: number of subsequent screenings, screening workflow adaptations during months $25-36$, the number of unique Veterans enrolled in each program during months 25-36, the number of unique providers who refer Veterans in each program during months 25-36, navigator retention, and sustained leadership buy-in (Table 1). We will also continue to track radiologists' and lung cancer screening navigators' continued adherence to the VA-PALS ELCAP Management System per the fidelity measures described in the Implementation Section above.

\section{Process Maps and Adaptations}

Each VA-PALS site will describe their initial processes of clinical workflow, which will be used to generate a process map at the start of implementation. These process maps will be generated via telephone interviews with each site's lung cancer screening navigator. Each map documents the site's method of conducting patient identification, eligibility confirmation, smoking cessation counseling, shared decisionmaking, appointment scheduling, LDCT appointment, communication of results and follow-up scans. Each site will be contacted every 6 months to review their process map and delineate workflow adaptations as implementation matures. Using the Framework for Reporting Adaptations and Modifications to Evidence Based Interventions (FRAME), ${ }^{46}$ we seek to understand how and why processes are adapted as well as how these adaptations influence implementation outcomes over time. Adaptations will be noted across the following FRAME domains: 1) when and how over the course of implementation were modifications made, 2) were these changes planned and proactive (e.g., intentional 
adaptation) or unplanned and reactive (e.g., in response to other forces), 3) who decided changes were necessary, 4) what was modified, 5) at what level in the system of delivery were changes made, 6) what types of changes were made in content or context, and 7) the reasons modifications were made and what contextual drivers were at play. Once process maps are developed or revised, they will be reviewed with each site for accuracy. Adaptations will be correlated with implementation outcomes (workflow, barriers and facilitators).

\section{Qualitative Evaluation}

Qualitative data will supplement the quantitative measures to recognize elements that were successfully implemented, and elements that posed a challenge at each site (Table 2). In-depth interviews among providers, staff and leadership at five sites with different process maps will be used to assess barriers and facilitators around the main factors related to implementation. Key questions asked will be: (1) "Tell me about what role you currently have in the lung cancer screening program at your VA" (CFIR individual/team characteristics); (2) "What is difficult about implementing a lung cancer screening program?" (RE-AIM implementation); (3) "How well does lung cancer screening fit with existing processes and practices in your VA?" (inner setting, implementation climate, compatibility); (4) "Are meetings, such as staff meetings, held regularly to discuss work process and practices such as lung cancer screening?" (inner setting - network and communication); (5) "What could help you to continue to perform highquality LDCT screening in your VA?" (RE-AIM maintenance). Targeted participants for interviews include primary care and radiology providers, staff, and leaders. All interviews will be audio-recorded and transcribed for subsequent thematic analysis, a standardized system that produces valid and reliable interpretations. All transcripts will be coded to establish a hierarchical coding system that categorizes comments contextually into themes that occur across multiple interviewees. ${ }^{47,48}$

\section{Discussion}

This report presents a structured and comprehensive evaluation protocol that will assess lung cancer screening program implementation across multiple VAMCs within an integrated healthcare system that has a decentralized leadership structure. ${ }^{49}$ This affords an opportunity to evaluate lung cancer screening program implementation in disparate cultures and clinical environments where priorities and resources may vary. The protocol will assess clinical process adaptations over time and examine how these adaptations influence implementation. The measures described and the overall program evaluation will generate knowledge that may influence the implementation of lung cancer screening programs more broadly throughout the VHA and beyond. It may help address the current national estimates that demonstrate exceedingly low rates of lung screening across the US. ${ }^{29-32}$

This program evaluation will advance the field of implementation science primarily through its theorybased approach. We will explore the interaction of strategies that act at the team, intervention and process of care levels (i.e. navigators, phantoms, management system) with constructs within implementation science frameworks, or perhaps, discover new constructs that are important in 
implementation of complex, imaging-based screening programs. Furthermore, we will be the first to validate an organizational measurement tool ${ }^{34}$ in a large, VHA population. Finally, we will assess the Veteran reach of lung cancer screening at multiple points along the screening pathway and explore barriers of rural Veterans and adaptations to screening programs over time, areas that have not been well studied in the VHA.

There are several unique and important challenges in implementing lung cancer screening compared to other cancer screenings that may be contributing to delayed uptake since publication of the USPSTF recommendations in 2014. First, identification of eligible individuals at-risk is difficult because this step depends upon accurate smoking histories, which are often unavailable, recorded incorrectly or in an unstructured format in the medical record. ${ }^{26,50}$ Then, if eligible individuals are identified, screening participants and providers are encouraged (and required by CMS for reimbursement) to engage in shared decision-making during which the potential benefits and harms of lung cancer screening are discussed; this requires time as well as a clinician who is confident in their ability to perform a shared decisionmaking discussion. ${ }^{13,51}$ Furthermore, programs are encouraged to incorporate smoking cessation services for current smokers, which is critically important but adds time and requires clinician familiarity with this service. ${ }^{12,13}$ VA-PALS programs plan to address these challenges by shifting some of these tasks away from busy primary care clinicians, streamlining workflow, and coordinating downstream screening-related activities. This program evaluation can shed more light on this model.

There are several operational considerations in this program evaluation plan. Some measures of program effectiveness (clinical outcomes) rely upon the timing of the installation of the VAPALS-ELCAP Management System at all 10 sites. This is also during a time when the VHA is planning to transition its electronic health record system to Cerner. The VAPALS-ELCAP Management System will be open-source and compatible with Cerner, though such transition may interrupt its functionality. Next, although we describe a comprehensive, theory-based program evaluation, additional limitations may emerge given a reliance on surveys and in-depth interviews to capture patient and provider experiences. As with all survey and qualitative research, self-reported outcomes are limited by recall bias, social desirability bias, and selection bias. We will attempt to overcome these challenges by seeking a high response-rate with local champions and research incentives. We will also conduct a sufficient number of interviews to reach thematic saturation. Another consideration is that a few of the data fields within the VAPALS-ELCAP Management System allow for free text in which users can type their individual responses. The study team will need to analyze these data manually, which may lead to potential misclassification or misinterpretation. There are also some measures that are not directly captured by the VAPALS-ELCAP Management System, such as how communication of screening results are relayed to patients and providers. The study team will rely on site self-reporting for these measures. Our denominator is imperfect as some sites may use more broad eligibility criteria and smoking histories are not accurately captured in the electronic health record. However, in order to have a consistent denominator across all VAMCs, we will use the same age criteria and estimate the proportion of those who are age appropriate for screening and meet smoking history criteria according to a prior study. ${ }^{26,32}$ Finally, the USPSTF is expected to expand 
the eligible screening population to include a younger age (starting at age 50) and less smoking history (at least 20 pack-years) in the coming months. ${ }^{22}$ This will increase the reach of Veterans, making lung cancer screening a routine service to an even larger population.

In summary, we report a theory-based, comprehensive program evaluation protocol for a multi-site lung cancer screening initiative that describes implementation and clinical outcomes. The results from this program evaluation will generate new knowledge that may influence the implementation of lung cancer screening programs more broadly as well as advance our scientific understanding of implementation of image-based screening tools in diverse settings.

\section{Abbreviations}




\begin{tabular}{|c|c|}
\hline CDW & Corporate Data Warehouse \\
\hline CFIR & Consolidated Framework for Implementation Science Research \\
\hline CMS & Centers for Medicare \& Medicaid Services \\
\hline CPRS & Computerized Patient Record System \\
\hline СT & Computerized Tomography \\
\hline ELCAP & Early Lung Cancer Action Program \\
\hline FRAME & $\begin{array}{l}\text { Framework for Reporting Adaptations and Modifications to Evidence Based } \\
\text { Interventions }\end{array}$ \\
\hline GRECC & Geriatric Research Education Clinical Center \\
\hline I-ELCAP & International Early Lung Action Program \\
\hline LCS & Lung cancer screening \\
\hline LDCT & Low-dose computed tomography \\
\hline Lung-RADS & Lung Imaging Reporting and Data System \\
\hline MS-ELCAP & Mount Sinai Early Lung and Cardiac Action Program \\
\hline NELSON & The Danish-Belgian Lung Cancer Screening Trial \\
\hline NLST & National Lung Cancer Screening Trial \\
\hline NP & Nurse practitioner \\
\hline PET & Positron emission tomography \\
\hline PA & Physician assistant \\
\hline RE-AIM & Reach, Effectiveness, Adoption, Implementation and Maintenance \\
\hline SDM & Shared decision-making \\
\hline USPSTF & United States Preventive Services Task Force \\
\hline VAMC & Veterans Administration Medical Centers \\
\hline VA-PALS & VA Partnership to Increase Access to Lung Screening \\
\hline $\begin{array}{l}\text { VAPALS- } \\
\text { ELCAP }\end{array}$ & $\begin{array}{l}\text { VA Partnership to Increase Access to Lung Screening-Early Lung Cancer Action } \\
\text { Program }\end{array}$ \\
\hline VHA & Veterans Health Administration \\
\hline $\mathrm{VINCl}$ & VA Informatics and Computing Infrastructure \\
\hline
\end{tabular}

\section{Declarations}




\section{Ethics Approval}

This study was approved by the VA Central Institutional Review Board, VA Tennessee Valley Healthcare System Research \& Development Committee, the VA Organizational Assessment Sub-Committee, and the VA National Union.

\section{Consent for Publication}

Not applicable.

\section{Availability of Data and Material}

Datasets used in this study will be available to VA researchers in the VA's Corporate Data Warehouse upon appropriate VA ethics and data access approvals. De-identified, aggregated data from the VAPALSELCAP management and tracking system, interviews, and surveys will be available upon reasonable request to the corresponding author and with VA-PALS leadership approval.

\section{Competing Interests}

DFY is a named inventor on a number of patents and patent applications relating to the evaluation of diseases of the chest including measurement of nodules. Some of these, which are owned by Cornell Research Foundation (CRF), are non-exclusively licensed to General Electric. As an inventor of these patents, DFY is entitled to a share of any compensation which CRF may receive from its commercialization of these patents. He is also an equity owner in Accumetra, a privately held technology company committed to improving the science and practice of image-based decision making. DFY also serves on the advisory board of GRAIL. CIH is the President and serves on the board of the Early Diagnosis and Treatment Research Foundation. She receives no compensation from the Foundation. The Foundation is established to provide grants for projects, conferences, and public databases for research on early diagnosis and treatment of diseases. $\mathrm{ClH}$ is also a named inventor on a number of patents and patent applications relating to the evaluation of pulmonary nodules on CT scans of the chest which are owned by Cornell Research Foundation (CRF). Since 2009, ClH does not accept any financial benefit from these patents including royalties and any other proceeds related to the patents or patent applications owned by CRF. RA is employed by Accumetra and Paraxial and his family holds stock and other ownership interest in Accumetra, Paraxial, and Kitware. Accumetra currently has patents that have been issued and are pending.

\section{Funding}

Funding provided by the U.S. Department of Veterans Affairs (VA) Office of Rural Health (ORH). Visit www.ruralhealth.va.gov to learn more. This study was also supported in part by the Vanderbilt CTSA grant UL1 TR000445 from the National Center for Advancing Translational Sciences, National Institutes of Health and the Veterans Affairs Office of Academic Affiliations. Its contents are solely the responsibility of the authors and do not necessarily represent official views of the National Center for 
Advancing Translational Sciences, the National Institutes of Health, or the Veterans Health Administration.

\section{Authors Contributions}

JAL conceptualized the study, acquired funding, developed the methodology and planned analysis, wrote the original draft, and reviewed, edited, and approved the final draft. LBS conceptualized the study, acquired funding, developed the methodology and planned analysis, reviewed, edited, and approved the final draft. $\mathrm{ClH}$ provided resources for the study, validated the study design, designed and provided the original software to be used for the screening management, data curation and quality assurance, edited the original draft, reviewed and approved the final draft. DFY provided resources for the study, validated the planned study, edited the original draft, reviewed and approved the final draft. SMA provided resources for the study, validated the study design, designed the software to be used for data curation, edited the original draft, reviewed and approved the final draft. PM provided resources, designed the software to be used for data curation, reviewed and approved the final draft. RA provided resources for the study, designed and developed the software to be used for data curation, validated the study, edited the original draft, reviewed and approved the final draft. CA conceptualized the study, developed the methodology and planned analysis, supervised the study team, edited the original draft, reviewed and approved the final draft. BP conceptualized the study, developed the methodology and planned analysis, edited the original draft, reviewed and approved the final draft. CJL conceptualized the study, developed the methodology and planned analysis, supervised the study team, edited the original draft, edited and approved the final draft. CCL conceptualized the study, developed the methodology, supervised the study team, edited the original draft, reviewed and approved the final draft. RSD acquired funding to support the study, developed the methodology, provided resources for the study, supervised the study team, edited the original draft, reviewed and approved the final draft. TJV conceptualized the study, developed the methodology and planned analysis, supervised the study team, edited the original draft, edited and approved the final draft. PPM acquired funding to support the study, provided resources for the study, supervised the study team, edited the original draft, reviewed and approved the final draft. HML conceptualized the study, developed the methodology, supervised the study team, edited the original draft, reviewed and approved the final draft. SK conceptualized the study, developed the methodology, supervised the study team, edited the original draft, reviewed and approved the final draft. DM acquired funding to support the study, provided resources for the study, validated the study, edited the original draft, edited and approved the final draft. CLR conceptualized the study, acquired funding, developed the methodology and planned analysis, provided resources, project management, supervised the study team, reviewed, edited, and approved the final draft.

\section{Acknowledgements}

This material is based upon work supported by the U.S. Department of Veterans Affairs (VA) Office of Rural Health (ORH), VA Office of Academic Affiliations, VA National Quality Scholars Program, and with resources and use of facilities at VA Tennessee Valley Healthcare System in Nashville, Tennessee. 
The ELCAP Management System was donated to VA-PALS to be translated into an open source system, called VAPALS-ELCAP Management System.

\section{References}

1. American Cancer Society. Cancer Facts and Figures: American Cancer Society, 2020.

2. Henschke $\mathrm{Cl}$, McCauley DI, Yankelevitz DF, et al. Early Lung Cancer Action Project: overall design and findings from baseline screening. Lancet. 1999;354: 99-105.

3. Institute NC. National Cancer Advisory Board. September 23-24, 1999 Minutes. National Insitutes of Health. Available from URL:

https://deainfo.nci.nih.gov/advisory/ncab/archive/111_0999/ncab0999.pdf [accessed August 10, 2020].

4. International Early Lung Cancer Action Program Investigators, Henschke $\mathrm{Cl}$, Yankelevitz DF, et al. Survival of patients with stage I lung cancer detected on CT screening. N Engl J Med. 2006;355: 1763-1771.

5. National Lung Screening Trial Research T, Aberle DR, Adams AM, et al. Reduced lung-cancer mortality with low-dose computed tomographic screening. N Engl J Med. 2011;365: 395-409.

6. de Koning $\mathrm{HJ}$, van der Aalst CM, de Jong PA, et al. Reduced Lung-Cancer Mortality with Volume CT Screening in a Randomized Trial. N Engl J Med. 2020.

7. Wood DE, Eapen GA, Ettinger DS, et al. Lung cancer screening. J Natl Compr Canc Netw. 2012;10: 240-265.

8. Wender R, Fontham ET, Barrera E, Jr., et al. American Cancer Society lung cancer screening guidelines. CA Cancer J Clin. 2013;63: 107-117.

9. Jaklitsch MT, Jacobson FL, Austin JH, et al. The American Association for Thoracic Surgery guidelines for lung cancer screening using low-dose computed tomography scans for lung cancer survivors and other high-risk groups. J Thorac Cardiovasc Surg. 2012;144: 33-38.

10. Bach PB, Mirkin JN, Oliver TK, et al. Benefits and harms of CT screening for lung cancer: a systematic review. JAMA. 2012;307: 2418-2429.

11. Veronesi G, Baldwin DR, Henschke $\mathrm{Cl}$, et al. Recommendations for Implementing Lung Cancer Screening with Low-Dose Computed Tomography in Europe. Cancers (Basel). 2020;12.

12. Moyer VA, Force USPST. Screening for lung cancer: U.S. Preventive Services Task Force recommendation statement. Ann Intern Med. 2014;160: 330-338.

13. Centers for Medicare \& Medicaid Services. Decision memo for screening for lung cancer with low dose computed tomography (LDCT) (CAG-00439N). Available from URL:

https://www.cms.gov/medicare-coverage-database/details/nca-decision-memo.aspx?NCAld=274 [accessed January 4, 2018].

14. Ostroff JS, Buckshee N, Mancuso CA, Yankelevitz DF, Henschke Cl. Smoking cessation following CT screening for early detection of lung cancer. Prev Med. 2001;33: 613-621. 
15. Townsend CO, Clark MM, Jett JR, et al. Relation between smoking cessation and receiving results from three annual spiral chest computed tomography scans for lung carcinoma screening. Cancer. 2005;103: 2154-2162.

16. Anderson CM, Yip R, Henschke Cl, Yankelevitz DF, Ostroff JS, Burns DM. Smoking cessation and relapse during a lung cancer screening program. Cancer Epidemiol Biomarkers Prev. 2009;18: 34763483.

17. Styn MA, Land SR, Perkins KA, Wilson DO, Romkes M, Weissfeld JL. Smoking behavior 1 year after computed tomography screening for lung cancer: Effect of physician referral for abnormal CT findings. Cancer Epidemiol Biomarkers Prev. 2009;18: 3484-3489.

18. van der Aalst $\mathrm{CM}$, van den Bergh $\mathrm{KA}$, Willemsen $\mathrm{MC}$, de Koning HJ, van Klaveren RJ. Lung cancer screening and smoking abstinence: 2 year follow-up data from the Dutch-Belgian randomised controlled lung cancer screening trial. Thorax. 2010;65: 600-605.

19. Slatore CG, Baumann C, Pappas M, Humphrey LL. Smoking behaviors among patients receiving computed tomography for lung cancer screening. Systematic review in support of the U.S. preventive services task force. Ann Am Thorac Soc. 2014;11: 619-627.

20. Tanner NT, Kanodra NM, Gebregziabher M, et al. The Association between Smoking Abstinence and Mortality in the National Lung Screening Trial. Am J Respir Crit Care Med. 2016;193: 534-541.

21. Borondy Kitts AK, McKee AB, Regis SM, Wald C, Flacke S, McKee BJ. Smoking cessation results in a clinical lung cancer screening program. J Thorac Dis. 2016;8: S481-487.

22. U.S. Preventive Services Task Force. Lung Cancer: Screening. Draft Review. Available from URL: https://www.uspreventiveservicestaskforce.org/uspstf/document/draft-evidence-review/lung-cancerscreening-2020 [accessed August 10, 2020].

23. Brown DW. Smoking prevalence among US veterans. J Gen Intern Med. 2010;25: 147-149.

24. Odani S Al, Graffunder CM, Tynan MA, Armour BS. Tobacco Product Use Among Military Veterans United States, 2010-2015. In: Control CfD, editor. MMWR Morb Mortal Wkly Rep 2018;67:7-12.

25. McKee BJ, McKee AB, Flacke S, Lamb CR, Hesketh PJ, Wald C. Initial experience with a free, highvolume, low-dose CT lung cancer screening program. J Am Coll Radiol. 2013;10: 586-592.

26. Kinsinger LS, Anderson C, Kim J, et al. Implementation of Lung Cancer Screening in the Veterans Health Administration. JAMA Intern Med. 2017;177: 399-406.

27. Copeland A, Criswell A, Ciupek A, King JC. Effectiveness of Lung Cancer Screening Implementation in the Community Setting in the United States. J Oncol Pract. 2019;15: e607-e615.

28. Kinsinger LS, Atkins D, Provenzale D, Anderson C, Petzel R. Implementation of a new screening recommendation in health care: the Veterans Health Administration's approach to lung cancer screening. Ann Intern Med. 2014;161: 597-598.

29. Jemal A, Fedewa SA. Lung Cancer Screening With Low-Dose Computed Tomography in the United States-2010 to 2015. JAMA Oncol. 2017;3: 1278-1281. 
30. Pham D, Bhandari S, Oechsli M, Pinkston CM, Kloecker GH. Lung cancer screening rates: data from the lung cancer screening registry. Journal of Clinical Oncology. 2018;36.

31. Liu B, Dharmarajan K, Henschke Cl, Taioli E. State-Level Variations in the Utilization of Lung Cancer Screening Among Medicare Fee-for-Service Beneficiaries: An Analysis of the 2015 to 2017 Physician and Other Supplier Data. Chest. 2020;157: 1012-1020.

32. Lewis JA, Samuels LR, Denton J, Edwards GC, Matheny ME, Maiga A, Slatore CG, Grogan E, Kim J, Sherrier RH, Dittus RS, Massion PP, Keohane L, Nikpay S, Roumie CL. National Lung Cancer Screening Utilization Trends in the Veterans Health Adminstration. JNCI Cancer Spectrum. 2020;(in press).

33. Henschke Cl, Reeves A, Avila R, Moghanaki D, Jirapatnakul A, Yankelevitz DF. OA 06.03. An Open Source Lung Screening Management System. Journal of Thoracic Oncology. 2019;14: S220-S221.

34. Spalluto LB, Lewis JA, Callaway-Lane C, Stolldorf D, Prusaczyk B, Limper H, Audet CM, Vogus, T, Wiener R, Slatore CG, Yankelevitz DF, Henschke Cl, Dittus RS, Massion PP, Lindsell C, Kripalani S, Moghanaki D, Roumie, CL. P2.11-33 Organizational Readiness for Implementation of Lung Cancer Screening in a Veterans Affairs Healthcare System. Journal of Thoracic Oncology, 2019:S806.

35. Henschke Cl, Yip R, Shaham D, et al. The Regimen of Computed Tomography Screening for Lung Cancer: Lessons Learned Over 25 Years From the International Early Lung Cancer Action Program. J Thorac Imaging. 2020.

36. Fabbrini AE, Lillie SE, Partin MR, et al. Initial results of a lung cancer screening demonstration project: a local program evaluation. Am J Manag Care. 2018;24: 272-277.

37. Wood DE, Kazerooni E.A., Baum S.L., et al. NCCN Clinical Practices Guidelines in Oncology (NCCN Guidelines) for Lung Cancer Screening Version 1.2019. National Comprehensive Cancer Network, Inc. Available at NCCN.org. 2019.

38. Damschroder LJ, Aron DC, Keith RE, Kirsh SR, Alexander JA, Lowery JC. Fostering implementation of health services research findings into practice: a consolidated framework for advancing implementation science. Implement Sci. 2009;4: 50.

39. Rojas Smith L AM, Morss Dy S, et al. Contextual frameworks for research on the implementation of complex system interventions. Report No. 14-EHC014-EF ed. Rockville, MD: Agency for Healthcare Research and Quality, 2014.

40. Glasgow RE, Vogt TM, Boles SM. Evaluating the public health impact of health promotion interventions: the RE-AIM framework. Am J Public Health. 1999;89: 1322-1327.

41. Cragun D, DeBate RD, Vadaparampil ST, Baldwin J, Hampel H, Pal T. Comparing universal Lynch syndrome tumor-screening programs to evaluate associations between implementation strategies and patient follow-through. Genet Med. 2014;16: 773-782.

42. IELCAP Investigators. Screening Protocol. Available from URL: https://www.ielcap.org/sites/default/files/l-ELCAP-protocol.pdf [accessed August 10, 2020].

43. Shea CM, Jacobs SR, Esserman DA, Bruce K, Weiner BJ. Organizational readiness for implementing change: a psychometric assessment of a new measure. Implement Sci. 2014;9: 7. 
44. Weiner BJ, Amick H, Lee SY. Conceptualization and measurement of organizational readiness for change: a review of the literature in health services research and other fields. Med Care Res Rev. 2008;65: 379-436.

45. Weiner BJ. A theory of organizational readiness for change. Implement Sci. 2009;4: 67.

46. Wiltsey Stirman S, Baumann AA, Miller CJ. The FRAME: an expanded framework for reporting adaptations and modifications to evidence-based interventions. Implement Sci. 2019;14: 58.

47. Locke KD. Grounded Theory in Management Research. Thousand Oaks, CA: Sage Publications, 2001.

48. Charmaz K. Constructing Grounded Theory: A Practical Guide Through Qualitative Analysis. Thousand Oaks, CA: Sage Publications, 2006.

49. Kizer KW. From the Veterans Health Administration. JAMA. 1996;275: 1303.

50. Modin HE, Fathi JT, Gilbert CR, et al. Pack-Year Cigarette Smoking History for Determination of Lung Cancer Screening Eligibility. Comparison of the Electronic Medical Record versus a Shared Decisionmaking Conversation. Ann Am Thorac Soc. 2017;14: 1320-1325.

51. Young, S. Memorandum: Lung Cancer Screening with Low Dose Computed Tomography (VAIQ: 7845332). Veterans Affairs, November 27, 2017.

52. Veterans Health Administration. VA Locations. Available from URL: https://www.va.gov/findlocations/?facility Type=health [accessed March 4, 2020, 2020].

53. Veterans Health Administration. Interactive US Map. Available from URL: https://www.va.gov/directory/guide/map.asp?dnum=1 [accessed March 4, 2020, 2020].

54. Veterans Health Administration. Summary of VHA Facility Complexity Model. Available from URL: https://www.vendorportal.ecms.va.gov/FBODocumentServer/DocumentServer.aspx?

Documentld=2793591\&FileName=VA118-16-R-1059-A00002002. docx [accessed July 9, 2019].

\section{Tables}

Table 1: VA Partnership to increase Access to Lung Screening Program Evaluation Measures 


\begin{tabular}{|c|c|c|}
\hline $\begin{array}{l}\text { Framework(s) } \\
\text { Domain** }\end{array}$ & $\begin{array}{l}\text { Duration of } \\
\text { Measures } * *\end{array}$ & Measure \\
\hline
\end{tabular}

RE-AIM Reach/CFIR Implementation Measures

\begin{tabular}{|c|c|c|c|}
\hline $\begin{array}{l}\text { Short-term } \\
\text { \& Long- } \\
\text { term }\end{array}$ & $\begin{array}{l}\text { Number of } \\
\text { Veterans } \\
\text { potentially eligible } \\
\text { to participate }\end{array}$ & $\begin{array}{l}\text { Number of } \\
\text { inpatient/outpatient } \\
\text { Veterans per year per } \\
\text { facility age } 55-80 \text {; then } \\
\text { will estimate eligible } \\
\text { smoking history }(\sim 32 \% \\
\text { of age appropriate } \\
\text { Veterans based on prior } \\
\text { study })^{26}\end{array}$ & $\mathrm{VINCI}$ \\
\hline $\begin{array}{l}\text { Short-term } \\
\text { \& Long- } \\
\text { term }\end{array}$ & $\begin{array}{l}\text { Number of } \\
\text { Veterans } \\
\text { approached to } \\
\text { participate }\end{array}$ & $\begin{array}{l}\text { Number approached by } \\
\text { LCS program }\end{array}$ & $\begin{array}{l}\text { VAPALS- } \\
\text { ELCAP }\end{array}$ \\
\hline $\begin{array}{l}\text { Short-term } \\
\text { \& Long- } \\
\text { term }\end{array}$ & $\begin{array}{l}\text { Number of } \\
\text { Veterans eligible } \\
\text { and agreeing to } \\
\text { participate after } \\
\text { SDM }\end{array}$ & Eligible and agreeing & $\begin{array}{l}\text { VAPALS- } \\
\text { ELCAP }\end{array}$ \\
\hline $\begin{array}{l}\text { Short-term } \\
\text { \& Long- } \\
\text { term }\end{array}$ & $\begin{array}{l}\text { Number of } \\
\text { Veterans } \\
\text { completing initial } \\
\text { screening }\end{array}$ & Number screened & $\begin{array}{l}\text { CDW or } \\
\text { VAPALS- } \\
\text { ELCAP }\end{array}$ \\
\hline $\begin{array}{l}\text { Short-term } \\
\text { \& Long- } \\
\text { term }\end{array}$ & $\begin{array}{l}\text { Number of eligible } \\
\text { Veterans declining } \\
\text { screening before } \\
\text { SDM }\end{array}$ & $\begin{array}{l}\text { Number declined before } \\
\text { SDM }\end{array}$ & $\begin{array}{l}\text { VAPALS- } \\
\text { ELCAP }\end{array}$ \\
\hline $\begin{array}{l}\text { Short-term } \\
\text { \& Long- } \\
\text { term }\end{array}$ & $\begin{array}{l}\text { Number of eligible } \\
\text { Veterans declining } \\
\text { screening after } \\
\text { SDM }\end{array}$ & $\begin{array}{l}\text { Number declined after } \\
\text { SDM }\end{array}$ & $\begin{array}{l}\text { VAPALS- } \\
\text { ELCAP }\end{array}$ \\
\hline $\begin{array}{l}\text { Short-term } \\
\text { \& Long- } \\
\text { term }\end{array}$ & $\begin{array}{l}\text { Number of LDCTs } \\
\text { ordered }\end{array}$ & LDCT ordered & $\begin{array}{l}\text { CDW or } \\
\text { VAPALS- } \\
\text { ELCAP }\end{array}$ \\
\hline $\begin{array}{l}\text { Short-term } \\
\text { \& Long- } \\
\text { term }\end{array}$ & $\begin{array}{l}\text { Number of initial } \\
\text { LDCTs ordered }\end{array}$ & Initial LDCTs ordered & $\begin{array}{l}\text { CDW or } \\
\text { VAPALS- } \\
\text { ELCAP }\end{array}$ \\
\hline $\begin{array}{l}\text { Short-term } \\
\text { \& Long- } \\
\text { term }\end{array}$ & $\begin{array}{l}\text { Veteran } \\
\text { demographic } \\
\text { information }\end{array}$ & $\begin{array}{l}\text { Age, ethnicity, gender, } \\
\text { smoking history, } \\
\text { rural/urban status of } \\
\text { Veterans approached } \\
\text { (accepted and declined } \\
\text { screening) }\end{array}$ & $\begin{array}{l}\text { CDW and } \\
\text { VAPALS- } \\
\text { ELCAP }\end{array}$ \\
\hline Short-term & Method of & Outreach vs. referral & VAPALS- \\
\hline
\end{tabular}


\& Long- program entry ELCAP term

RE-AIM

Effectiveness/CFIR

Clinical Effectiveness

\begin{tabular}{|c|c|c|c|}
\hline $\begin{array}{l}\text { Short-term } \\
\text { \& Long- } \\
\text { term }\end{array}$ & $\begin{array}{l}\text { Exam results } \\
\text { based on Lung- } \\
\text { RADS/I-ELCAP }\end{array}$ & $\begin{array}{l}\text { Number of screenings } \\
\text { in each Lung- } \\
\text { RADS/ELCAP category }\end{array}$ & $\begin{array}{l}\text { VAPALS- } \\
\text { ELCAP }\end{array}$ \\
\hline $\begin{array}{l}\text { Short-term } \\
\text { \& Long- } \\
\text { term }\end{array}$ & $\begin{array}{l}\text { Number of } \\
\text { cancers detected }\end{array}$ & $\begin{array}{l}\text { Total number lung } \\
\text { cancers detected }\end{array}$ & $\begin{array}{l}\text { CDW or } \\
\text { VAPALS- } \\
\text { ELCAP }\end{array}$ \\
\hline $\begin{array}{l}\text { Short-term } \\
\text { \& Long- } \\
\text { term }\end{array}$ & $\begin{array}{l}\text { Pathologic/clinical } \\
\text { stage of screen } \\
\text { detected cancers }\end{array}$ & $\begin{array}{l}\text { Stage of each cancer } \\
\text { detected }\end{array}$ & $\begin{array}{l}\text { CDW and } \\
\text { chart } \\
\text { review or } \\
\text { VAPALS- } \\
\text { ELCAP }\end{array}$ \\
\hline $\begin{array}{l}\text { Short-term } \\
\& \text { Long- } \\
\text { term }\end{array}$ & $\begin{array}{l}\text { Histologic type } \\
\text { screen detected } \\
\text { cancers }\end{array}$ & $\begin{array}{l}\text { Type of each cancer } \\
\text { detected }\end{array}$ & $\begin{array}{l}\text { CDW and } \\
\text { chart } \\
\text { review or } \\
\text { VAPALS- } \\
\text { ELCAP }\end{array}$ \\
\hline $\begin{array}{l}\text { Short-term } \\
\text { \& Long- } \\
\text { term }\end{array}$ & $\begin{array}{l}\text { Number/type non- } \\
\text { lung abnormalities } \\
\text { detected by } \\
\text { screening }\end{array}$ & $\begin{array}{l}\text { Incidental findings } \\
\text { detected }\end{array}$ & $\begin{array}{l}\text { VAPALS- } \\
\text { ELCAP }\end{array}$ \\
\hline $\begin{array}{l}\text { Short-term } \\
\text { \& Long- } \\
\text { term }\end{array}$ & $\begin{array}{l}\text { Number and type } \\
\text { of downstream } \\
\text { interventions }\end{array}$ & $\begin{array}{l}\text { Number PET scans, } \\
\text { bronchoscopies, } \\
\text { mediastinoscopies, } \\
\text { biopsies }\end{array}$ & $\begin{array}{l}\text { CDW or } \\
\text { VAPALS- } \\
\text { ELCAP }\end{array}$ \\
\hline $\begin{array}{l}\text { Short-term } \\
\text { \& Long- } \\
\text { term }\end{array}$ & $\begin{array}{l}\text { Number and type } \\
\text { of treatments }\end{array}$ & $\begin{array}{l}\text { Number of surgeries, } \\
\text { radiation therapy, } \\
\text { systemic therapy }\end{array}$ & $\begin{array}{l}\text { CDW or } \\
\text { VAPALS- } \\
\text { ELCAP }\end{array}$ \\
\hline Long-term & Mortality & $\begin{array}{l}\text { Survival rate of } \\
\text { Veterans screened in } \\
\text { lung cancer screening } \\
\text { programs }\end{array}$ & $\begin{array}{l}\text { CDW and } \\
\text { VAPALS- } \\
\text { ELCAP }\end{array}$ \\
\hline $\begin{array}{l}\text { Short-term } \\
\text { \& Long- } \\
\text { term }\end{array}$ & $\begin{array}{l}\text { Number smoking } \\
\text { cessation referrals }\end{array}$ & $\begin{array}{l}\text { Number of referrals } \\
\text { placed to smoking } \\
\text { cessation program }\end{array}$ & $\begin{array}{l}\text { CDW or } \\
\text { VAPALS- } \\
\text { ELCAP }\end{array}$ \\
\hline $\begin{array}{l}\text { Short-term } \\
\text { \& Long- } \\
\text { term }\end{array}$ & $\begin{array}{l}\text { Number quit } \\
\text { attempts }\end{array}$ & $\begin{array}{l}\text { Number of times a } \\
\text { Veteran attempts to quit } \\
\text { smoking }\end{array}$ & $\begin{array}{l}\text { VAPALS- } \\
\text { ELCAP }\end{array}$ \\
\hline $\begin{array}{l}\text { Short-term } \\
\& \text { Long- } \\
\text { term }\end{array}$ & $\begin{array}{l}\text { Number } \\
\text { successful quit } \\
\text { attempts }\end{array}$ & $\begin{array}{l}\text { Number of times a } \\
\text { Veteran reports } \\
\text { successfully quitting for } \\
\text { at least } 6 \text { months }\end{array}$ & $\begin{array}{l}\text { VAPALS- } \\
\text { ELCAP }\end{array}$ \\
\hline
\end{tabular}




\begin{tabular}{|c|c|c|c|c|}
\hline & $\begin{array}{l}\text { Short-term } \\
\text { \& Long- } \\
\text { term }\end{array}$ & $\begin{array}{l}\text { Types of smoking } \\
\text { cessation } \\
\text { resources utilized }\end{array}$ & $\begin{array}{l}\text { Number of medications } \\
\text { prescribed for smoking } \\
\text { cessation (nicotine } \\
\text { replacement, } \\
\text { varenicline, bupropion) }\end{array}$ & $\begin{array}{l}\text { VAPALS- } \\
\text { ELCAP }\end{array}$ \\
\hline & $\begin{array}{l}\text { Short-term } \\
\text { \& Long- } \\
\text { term }\end{array}$ & $\begin{array}{l}\text { Program referral to } \\
\text { contact by } \\
\text { navigator }\end{array}$ & $\begin{array}{l}\text { Number of days from } \\
\text { referral date to program } \\
\text { contact on intake form } \\
\text { (for programs with } \\
\text { referral orders) }\end{array}$ & $\begin{array}{l}\text { VAPALS- } \\
\text { ELCAP }\end{array}$ \\
\hline & $\begin{array}{l}\text { Short-term } \\
\text { \& Long- } \\
\text { term }\end{array}$ & $\begin{array}{l}\text { Exam order to date } \\
\text { of scan }\end{array}$ & $\begin{array}{l}\text { Number of days from } \\
\text { order of LDCT } \\
\text { screening to scan } \\
\text { performance }\end{array}$ & $\begin{array}{l}\text { VAPALS- } \\
\text { ELCAP }\end{array}$ \\
\hline & $\begin{array}{l}\text { Short-term } \\
\text { \& Long- } \\
\text { term }\end{array}$ & $\begin{array}{l}\text { Scan to } \\
\text { intervention } \\
\text { performed }\end{array}$ & $\begin{array}{l}\text { Number of days from a } \\
\text { scan to a follow up } \\
\text { intervention (PET, } \\
\text { bronchoscopy, } \\
\text { pulmonology consult, } \\
\text { surgery) }\end{array}$ & $\begin{array}{l}\text { VAPALS- } \\
\text { ELCAP }\end{array}$ \\
\hline \multirow[t]{2}{*}{ Experiences } & Short-term & $\begin{array}{l}\text { Provider } \\
\text { Experience }\end{array}$ & $\begin{array}{l}\text { Provider experience in } \\
\text { lung cancer screening }\end{array}$ & Survey \\
\hline & Short-term & $\begin{array}{l}\text { Veteran } \\
\text { Experience }\end{array}$ & $\begin{array}{l}\text { Veteran experience in } \\
\text { lung cancer screening }\end{array}$ & Survey \\
\hline \multicolumn{5}{|l|}{$\begin{array}{l}\text { RE-AIM } \\
\text { Adoption/CFIR } \\
\text { Implementation } \\
\text { Measures }\end{array}$} \\
\hline & Short-term & VAMC location & $\begin{array}{l}\text { City where VAMC is } \\
\text { located }\end{array}$ & $\begin{array}{l}\text { CDW/VHA } \\
\text { website }^{52}\end{array}$ \\
\hline & Short-term & VISN & $\begin{array}{l}\text { VISN where VAMC is } \\
\text { located }\end{array}$ & $\begin{array}{l}\text { CDW/VHA } \\
\text { website }^{53}\end{array}$ \\
\hline & Short-term & U.S. Region & $\begin{array}{l}\text { U.S. Census Region } \\
\text { where VISN is located }\end{array}$ & $\begin{array}{l}\text { CDW/VHA } \\
\text { website }^{53}\end{array}$ \\
\hline & Short-term & Complexity Level & $\begin{array}{l}\text { Complexity Level of } \\
\text { VAMC } C^{\star \star \star}\end{array}$ & $\begin{array}{l}\text { CDW/VHA } \\
\text { website }^{54}\end{array}$ \\
\hline & Short-term & $\begin{array}{l}\text { First use of } \\
\text { VAPALS-ELCAP } \\
\text { software }\end{array}$ & $\begin{array}{l}\text { Date of first use of } \\
\text { VAPALS-ELCAP } \\
\text { Management System }\end{array}$ & $\begin{array}{l}\text { VA-PALS } \\
\text { leadership }\end{array}$ \\
\hline & Short-term & $\begin{array}{l}\text { First use of } \\
\text { phantom }\end{array}$ & $\begin{array}{l}\text { Date of first use of } \\
\text { phantom }\end{array}$ & $\begin{array}{l}\text { VA-PALS } \\
\text { leadership }\end{array}$ \\
\hline & Short-term & $\begin{array}{l}\text { Navigator position } \\
\text { posted }\end{array}$ & $\begin{array}{l}\text { Date the navigator } \\
\text { position was posted }\end{array}$ & $\begin{array}{l}\text { Interview } \\
\text { with VA- } \\
\text { PALS } \\
\text { champion }\end{array}$ \\
\hline
\end{tabular}




\begin{tabular}{|c|c|c|c|c|}
\hline & Short-term & $\begin{array}{l}\text { Navigator official } \\
\text { start date }\end{array}$ & $\begin{array}{l}\text { Date the navigator } \\
\text { started the position }\end{array}$ & $\begin{array}{l}\text { Interview } \\
\text { with VA- } \\
\text { PALS } \\
\text { champion }\end{array}$ \\
\hline & Short-term & $\begin{array}{l}\text { Navigator training } \\
\text { date }\end{array}$ & $\begin{array}{l}\text { Date the navigator } \\
\text { attended I-ELCAP } \\
\text { training }\end{array}$ & $\begin{array}{l}\text { VA-PALS } \\
\text { leadership }\end{array}$ \\
\hline & Short-term & $\begin{array}{l}\text { Organizational } \\
\text { Readiness }\end{array}$ & $\begin{array}{l}\text { Organizational } \\
\text { readiness for lung } \\
\text { cancer screening in the } \\
\text { first } 12 \text { months of } \\
\text { screening program }\end{array}$ & Survey \\
\hline & Short-term & $\begin{array}{l}\text { Lung Cancer } \\
\text { Screening } \\
\text { Program Team } \\
\text { Characteristics }\end{array}$ & $\begin{array}{l}\text { Roles and specialties of } \\
\text { all persons involved in } \\
\text { the operation of local } \\
\text { screening programs }\end{array}$ & $\begin{array}{l}\text { Interviews } \\
\text { with } \\
\text { navigators } \\
\text { and } \\
\text { champions }\end{array}$ \\
\hline & Short-term & $\begin{array}{l}\text { Degree of } \\
\text { leadership buy-in }\end{array}$ & $\begin{array}{l}\text { Degree of leadership } \\
\text { support in form of } \\
\text { resources, meetings, } \\
\text { and communication in } \\
\text { first } 12 \text { months }\end{array}$ & Interviews \\
\hline & Short-term & $\begin{array}{l}\text { Alignment with } \\
\text { VISN priorities }\end{array}$ & $\begin{array}{l}\text { Alignment with VISN } \\
\text { priorities in first } 24 \\
\text { months of program }\end{array}$ & Interviews \\
\hline & Short-term & $\begin{array}{l}\text { Unique provider } \\
\text { referrals }\end{array}$ & $\begin{array}{l}\text { Unique provider } \\
\text { referrals in months 1-24 }\end{array}$ & $\begin{array}{l}\text { CDW or } \\
\text { VAPALS- } \\
\text { ELCAP }\end{array}$ \\
\hline & Short-term & $\begin{array}{l}\text { Referring provider } \\
\text { characteristics }\end{array}$ & $\begin{array}{l}\text { Referring provider type } \\
\text { and specialty }\end{array}$ & $\begin{array}{l}\text { CDW or } \\
\text { VAPALS- } \\
\text { ELCAP }\end{array}$ \\
\hline \multicolumn{5}{|l|}{$\begin{array}{l}\text { RE-AIM } \\
\text { Implementation/CFIR } \\
\text { Implementation } \\
\text { Measures }\end{array}$} \\
\hline & $\begin{array}{l}\text { Short-term } \\
\text { \& Long- } \\
\text { term }\end{array}$ & $\begin{array}{l}\text { Navigator length } \\
\text { of work }\end{array}$ & $\begin{array}{l}\text { Number of days each } \\
\text { navigator works as the } \\
\text { screening program } \\
\text { navigator }\end{array}$ & $\begin{array}{l}\text { Interviews } \\
\text { with VA- } \\
\text { PALS } \\
\text { champion } \\
\text { and } \\
\text { leadership }\end{array}$ \\
\hline & $\begin{array}{l}\text { Short-term } \\
\text { \& Long- } \\
\text { term }\end{array}$ & $\begin{array}{l}\text { Navigator } \\
\text { workload }\end{array}$ & $\begin{array}{l}\text { Volume of Veterans } \\
\text { encountered by each } \\
\text { navigator }\end{array}$ & $\begin{array}{l}\text { CDW or } \\
\text { VAPALS- } \\
\text { ELCAP }\end{array}$ \\
\hline & $\begin{array}{l}\text { Short-term } \\
\text { \& Long- } \\
\text { term }\end{array}$ & $\begin{array}{l}\text { Navigator use of } \\
\text { VAPALS-ELCAP } \\
\text { software }\end{array}$ & $\begin{array}{l}\text { Number of screening- } \\
\text { related activities } \\
\text { (approach Veterans, } \\
\text { enroll Veterans, write }\end{array}$ & $\begin{array}{l}\text { Interview } \\
\text { with } \\
\text { navigators }\end{array}$ \\
\hline
\end{tabular}

Page 25/35 


\begin{tabular}{|c|c|c|c|c|}
\hline & & & $\begin{array}{l}\text { notes, track screening } \\
\text { results, manage follow- } \\
\text { up procedures, manage } \\
\text { annual screening } \\
\text { follow-up) that } \\
\text { navigator uses VAPALS- } \\
\text { ELCAP and/or other } \\
\text { tracking system }\end{array}$ & $\begin{array}{l}\text { for process } \\
\text { maps }\end{array}$ \\
\hline & $\begin{array}{l}\text { Short-term } \\
\text { \& Long- } \\
\text { term }\end{array}$ & $\begin{array}{l}\text { Radiologist use of } \\
\text { VAPALS-ELCAP } \\
\text { software }\end{array}$ & $\begin{array}{l}\text { Proportion of } \\
\text { radiologists using } \\
\text { VAPALS-ELCAP } \\
\text { software out of all } \\
\text { radiologists who } \\
\text { interpret LDCTs at each } \\
\text { site }\end{array}$ & $\begin{array}{l}\text { Interview } \\
\text { with } \\
\text { radiology } \\
\text { champion }\end{array}$ \\
\hline & $\begin{array}{l}\text { Short-term } \\
\text { \& Long- } \\
\text { term }\end{array}$ & Phantom use & $\begin{array}{l}\text { Dates phantom is } \\
\text { scanned by CT and } \\
\text { dates adjustments are } \\
\text { made to CT imaging } \\
\text { protocol }\end{array}$ & $\begin{array}{l}\text { Interview } \\
\text { with local } \\
\text { radiology } \\
\text { champion } \\
\text { and } \\
\text { VAPALS } \\
\text { leadership }\end{array}$ \\
\hline \multirow[t]{5}{*}{ FRAME } & Long-term & $\begin{array}{l}\text { Adaptations to } \\
\text { program }\end{array}$ & $\begin{array}{l}\text { Individual site } \\
\text { adaptations }\end{array}$ & $\begin{array}{l}\text { Interviews } \\
\text { with VA- } \\
\text { PALS } \\
\text { navigators }\end{array}$ \\
\hline & $\begin{array}{l}\text { Short-term } \\
\text { \& Long- } \\
\text { term }\end{array}$ & $\begin{array}{l}\text { Quality of LDCT } \\
\text { exams }\end{array}$ & $\begin{array}{l}\text { Phantom used, } \\
\text { feedback incorporated } \\
\text { into imaging protocol }\end{array}$ & $\begin{array}{l}\text { Interviews } \\
\text { with VA- } \\
\text { PALS } \\
\text { leadership }\end{array}$ \\
\hline & Short-term & $\begin{array}{l}\text { Navigator } \\
\text { permanent } \\
\text { position }\end{array}$ & $\begin{array}{l}\text { Date that navigator } \\
\text { position was made } \\
\text { permanent }\end{array}$ & $\begin{array}{l}\text { Interviews } \\
\text { with VA- } \\
\text { PALS } \\
\text { champion }\end{array}$ \\
\hline & Short-term & $\begin{array}{l}\text { Barriers and } \\
\text { facilitators to } \\
\text { implementing lung } \\
\text { cancer screening } \\
\text { program }\end{array}$ & $\begin{array}{l}\text { Qualitative data from } \\
\text { in-depth interviews }\end{array}$ & $\begin{array}{l}\text { Interviews } \\
\text { with VA- } \\
\text { PALS } \\
\text { providers, } \\
\text { staff, } \\
\text { leadership }\end{array}$ \\
\hline & $\begin{array}{l}\text { Short-term } \\
\text { \& Long- } \\
\text { term }\end{array}$ & Process maps & $\begin{array}{l}\text { Description of how } \\
\text { each program performs: } \\
\text { Veteran identification, } \\
\text { eligibility confirmation, } \\
\text { smoking cessation } \\
\text { services, shared } \\
\text { decision-making, } \\
\text { screening exam } \\
\text { performed, delivery of } \\
\text { results, downstream } \\
\text { activities for abnormal } \\
\text { studies }\end{array}$ & $\begin{array}{l}\text { Interviews } \\
\text { with VA- } \\
\text { PALS } \\
\text { navigators }\end{array}$ \\
\hline
\end{tabular}




RE-AIM
Maintenance/CFIR
Implementation
Measures

\begin{tabular}{|c|c|c|c|}
\hline $\begin{array}{l}\text { Short-term } \\
\text { \& Long- } \\
\text { term }\end{array}$ & $\begin{array}{l}\text { Number of } \\
\text { subsequent LDCTs } \\
\text { ordered }\end{array}$ & $\begin{array}{l}\text { Number of subsequent } \\
\text { annual LDCTs ordered } \\
\text { after initial LDCT }\end{array}$ & $\begin{array}{l}\text { CDW or } \\
\text { VAPALS- } \\
\text { ELCAP }\end{array}$ \\
\hline $\begin{array}{l}\text { Short-term } \\
\text { \& Long- } \\
\text { term }\end{array}$ & $\begin{array}{l}\text { Screening } \\
\text { adherence }\end{array}$ & $\begin{array}{l}\text { Percent Veterans } \\
\text { returning for annual } \\
\text { screening within 6-18 } \\
\text { months of previous } \\
\text { screening }\end{array}$ & $\begin{array}{l}\text { CDW or } \\
\text { VAPALS- } \\
\text { ELCAP }\end{array}$ \\
\hline $\begin{array}{l}\text { Short-term } \\
\text { \& Long- } \\
\text { term }\end{array}$ & $\begin{array}{l}\text { Radiologist } \\
\text { adherence to } \\
\text { VAPALS-ELCAP } \\
\text { software }\end{array}$ & $\begin{array}{l}\text { Percent radiologists } \\
\text { utilizing software after } \\
\text { first } 6 \text { months }\end{array}$ & $\begin{array}{l}\text { Interviews } \\
\text { with VA- } \\
\text { PALS } \\
\text { radiologists }\end{array}$ \\
\hline Long-term & $\begin{array}{l}\text { Navigator } \\
\text { retention }\end{array}$ & $\begin{array}{l}\text { Number navigators } \\
\text { retained in months 25- } \\
36 \text { months, turnover at } \\
\text { individual sites }\end{array}$ & $\begin{array}{l}\text { Interviews } \\
\text { with VA- } \\
\text { PALS } \\
\text { leadership } \\
\text { and site } \\
\text { champions }\end{array}$ \\
\hline Long-term & $\begin{array}{l}\text { Unique provider } \\
\text { referrals }\end{array}$ & $\begin{array}{l}\text { Unique provider } \\
\text { referrals in months 25- } \\
36\end{array}$ & $\begin{array}{l}\text { CDW or } \\
\text { VAPALS- } \\
\text { ELCAP }\end{array}$ \\
\hline Long-term & $\begin{array}{l}\text { Unique Veteran } \\
\text { referrals }\end{array}$ & $\begin{array}{l}\text { Unique Veteran referrals } \\
\text { in months } 25-36\end{array}$ & $\begin{array}{l}\text { CDW or } \\
\text { VAPALS- } \\
\text { ELCAP }\end{array}$ \\
\hline Long-term & Process maps & $\begin{array}{l}\text { Description of how } \\
\text { each program performs: } \\
\text { Veteran identification, } \\
\text { eligibility confirmation, } \\
\text { smoking cessation } \\
\text { services, shared } \\
\text { decision-making, } \\
\text { screening exam } \\
\text { performed, delivery of } \\
\text { results, downstream } \\
\text { activities for abnormal } \\
\text { studies in months 25-36 }\end{array}$ & $\begin{array}{l}\text { Interviews } \\
\text { with } \\
\text { navigators }\end{array}$ \\
\hline Long-term & $\begin{array}{l}\text { Sustained } \\
\text { leadership buy-in }\end{array}$ & $\begin{array}{l}\text { Amount and type of } \\
\text { leadership support of } \\
\text { lung cancer screening } \\
\text { program in months } 25 \text { - } \\
36\end{array}$ & $\begin{array}{l}\text { Interviews } \\
\text { with } \\
\text { leadership, } \\
\text { VA-PALS } \\
\text { champions }\end{array}$ \\
\hline Long-term & Fidelity measures & $\begin{array}{l}\text { Fidelity measures } \\
\text { defined above will be } \\
\text { followed during months } \\
25-36\end{array}$ & $\begin{array}{l}\text { Interviews } \\
\text { with VA- } \\
\text { PALS } \\
\text { champions, } \\
\text { leadership, } \\
\text { and }\end{array}$ \\
\hline
\end{tabular}


Table 1 Legend: *Domains are based on the Reach, Effectiveness, Adoption, Implementation, and Maintenance (RE-AIM) Framework, the Consolidated Framework for Implementation Research (CFIR), and the Framework for Reporting Adaptations and Modifications to Evidence-based Interventions (FRAME) frameworks $38,40,46 ; * \star$ Short-term refers to $\leq 24$ months since start of the program; Long-term refers to > 24 months since start of program. Providers interviewed include physicians and advanced practice providers in primary care, radiology, and the program clinical coordinators; VA-PALS refers to VA Partnership to increase Access to Lung Screening; VINCI refers to VA Informatics and Computing Infrastructure; CDW refers to the Veterans Health Administration's Corporate Data Warehouse; SDM refers to shared decision-making; VAPALS-ELCAP refers to the VAPALS-ELCAP Management System to be developed by VA-PALS ***VAMC complexity score consists of five complexity levels: $1 \mathrm{a}, 1 \mathrm{~b}, 1 \mathrm{c}, 2$, and 3 , where $1 \mathrm{a}$ is the most complex and 3 is the least complex. This ranking system takes the following into consideration: (1) volume and patient case mix, (2) clinical services provided, (3) patient risk calculated from VA patient diagnosis, (4) total resident slots, (5) an index of multiple residency programs at a single facility, (6) total amount of research dollars, and (7) the number of specialized clinical services. ${ }^{54}$

Table 2: Qualitative Data Collection 


\begin{tabular}{|llll|}
\hline $\begin{array}{l}\text { Framework(s) } \\
\text { Domain* }\end{array}$ & $\begin{array}{l}\text { Interview } \\
\text { Type }\end{array}$ & Interviewee & Interview Items \\
$\begin{array}{llll}\text { CFIR Individual } \\
\text { Characteristics }\end{array}$ & $\begin{array}{l}\text { Barriers \& } \\
\text { Facilitators }\end{array}$ & $\begin{array}{l}\text { Provider, Staff, } \\
\text { Administrator }\end{array}$ & $\begin{array}{l}\text { How long have you been in your role in } \\
\text { radiology/primary care? }\end{array}$ \\
\hline $\begin{array}{l}\text { CFIR Individual } \\
\text { Characteristics }\end{array}$ & $\begin{array}{l}\text { Barriers \& } \\
\text { Facilitators }\end{array}$ & $\begin{array}{l}\text { Provider, Staff, } \\
\text { Administrator }\end{array}$ & $\begin{array}{l}\text { Where else have you practiced/worked in the } \\
\text { past } 5 \text { years? }\end{array}$ \\
\hline $\begin{array}{l}\text { CFIR Individual } \\
\text { Characteristics }\end{array}$ & $\begin{array}{l}\text { Barriers \& } \\
\text { Facilitators }\end{array}$ & $\begin{array}{l}\text { Provider, Staff, } \\
\text { Administrator }\end{array}$ & $\begin{array}{l}\text { What percentage of your clinical practice live in a } \\
\text { rural area? (providers only) }\end{array}$ \\
\hline $\begin{array}{l}\text { CFIR Individual } \\
\text { Characteristics }\end{array}$ & $\begin{array}{l}\text { Barriers \& } \\
\text { Facilitators }\end{array}$ & $\begin{array}{l}\text { Provider, Staff, } \\
\text { Administrator }\end{array}$ & $\begin{array}{l}\text { Tell me about your thoughts on lung cancer } \\
\text { screening. }\end{array}$ \\
\hline
\end{tabular}

$\begin{array}{llll}\text { CFIR Individual } & \text { Barriers \& } & \text { Provider, Staff, } & \text { Tell me about your role in lung cancer screening. } \\ \text { Characteristics } & \text { Facilitators } & \text { Administrator }\end{array}$

$\begin{array}{llll}\text { CFIR Measures } & \text { Barriers \& } & \text { Provider, Staff, } & \text { What have been the difficulties in performing } \\ \text { of } & \text { Facilitators } & \text { Administrator } & \text { lung cancer screening? }\end{array}$

Implementation;

RE-AIM

Implementation
CFIR Measures of
Barriers \& Provider, Staff Facilitators
What have been the difficulties in implementing a lung cancer screening program?

Implementation;

RE-AIM

Implementation

\begin{tabular}{|c|c|c|c|}
\hline $\begin{array}{l}\text { CFIR Measures } \\
\text { of } \\
\text { Implementation; }\end{array}$ & $\begin{array}{l}\text { Barriers \& } \\
\text { Facilitators }\end{array}$ & Provider & $\begin{array}{l}\text { What has been difficult in screening Veterans } \\
\text { from rural areas for lung cancer? }\end{array}$ \\
\hline
\end{tabular}

RE-AIM

Implementation

$\begin{array}{llll}\text { CFIR Measures } & \text { Barriers \& } & \text { Provider } & \text { What could help you perform lung cancer } \\ \text { of } & \text { Facilitators } & & \text { screening? }\end{array}$

RE-AIM

Implementation

$\begin{array}{llll}\text { CFIR Measures } & \text { Barriers \& } & \text { Provider } & \text { What could help you to increase screening } \\ \text { of } & \text { Facilitators } & & \text { amongst rural Veterans? } \\ \text { Implementation; } & & \\ \text { RE-AIM } & & \\ \text { Implementation } & & \end{array}$

\begin{tabular}{|c|c|c|c|}
\hline $\begin{array}{l}\text { CFIR Measures } \\
\text { of } \\
\text { Implementation; } \\
\text { RE-AIM } \\
\text { Implementation }\end{array}$ & $\begin{array}{l}\text { Barriers \& } \\
\text { Facilitators }\end{array}$ & $\begin{array}{l}\text { Provider, Staff, } \\
\text { Administrators }\end{array}$ & $\begin{array}{l}\text { What kinds of changes in the current support } \\
\text { system could help you? }\end{array}$ \\
\hline $\begin{array}{l}\text { CFIR Process of } \\
\text { Lung Cancer } \\
\text { Screening }\end{array}$ & $\begin{array}{l}\text { Barriers \& } \\
\text { Facilitators }\end{array}$ & $\begin{array}{l}\text { Provider, Staff, } \\
\text { Administrators }\end{array}$ & $\begin{array}{l}\text { How well does lung cancer screening fit with the } \\
\text { existing work processes and practices in your } \\
\text { VA? }\end{array}$ \\
\hline
\end{tabular}




\begin{tabular}{|c|c|c|c|}
\hline $\begin{array}{l}\text { CFIR Team } \\
\text { Characteristics }\end{array}$ & $\begin{array}{l}\text { Barriers \& } \\
\text { Facilitators }\end{array}$ & Provider, Staff & $\begin{array}{l}\text { Are meetings held regularly to discuss work } \\
\text { processes and practices such as lung cancer } \\
\text { screening? }\end{array}$ \\
\hline $\begin{array}{l}\text { CFIR Measures } \\
\text { of } \\
\text { Implementation; } \\
\text { RE-AIM } \\
\text { Implementation }\end{array}$ & $\begin{array}{l}\text { Barriers \& } \\
\text { Facilitators }\end{array}$ & $\begin{array}{l}\text { Provider, Staff, } \\
\text { Administrators }\end{array}$ & $\begin{array}{l}\text { What is working well with lung cancer screening } \\
\text { at your VA? }\end{array}$ \\
\hline $\begin{array}{l}\text { CFIR Measures } \\
\text { of } \\
\text { Implementation; } \\
\text { RE-AIM } \\
\text { Implementation }\end{array}$ & $\begin{array}{l}\text { Barriers \& } \\
\text { Facilitators }\end{array}$ & Provider & $\begin{array}{l}\text { What is working well for screening Veterans who } \\
\text { live in rural areas? }\end{array}$ \\
\hline $\begin{array}{l}\text { CFIR Measures } \\
\text { of } \\
\text { Implementation; } \\
\text { RE-AIM } \\
\text { Maintenance }\end{array}$ & $\begin{array}{l}\text { Barriers \& } \\
\text { Facilitators }\end{array}$ & $\begin{array}{l}\text { Provider, Staff, } \\
\text { Administrators }\end{array}$ & $\begin{array}{l}\text { What are your hopes for the future of lung cancer } \\
\text { screening? }\end{array}$ \\
\hline $\begin{array}{l}\text { CFIR Measures } \\
\text { of } \\
\text { Implementation; } \\
\text { RE-AIM } \\
\text { Maintenance }\end{array}$ & $\begin{array}{l}\text { Barriers \& } \\
\text { Facilitators }\end{array}$ & $\begin{array}{l}\text { Provider, Staff, } \\
\text { Administrators }\end{array}$ & What could help maintain the program? \\
\hline $\begin{array}{l}\text { CFIR Individual } \\
\text { Characteristics }\end{array}$ & $\begin{array}{l}\text { Initial } \\
\text { Process } \\
\text { Map }\end{array}$ & $\begin{array}{l}\text { Program } \\
\text { Navigator }\end{array}$ & $\begin{array}{l}\text { Can you give me the date of the first day you } \\
\text { worked as the program navigator? }\end{array}$ \\
\hline $\begin{array}{l}\text { CFIR Individual } \\
\text { Characteristics }\end{array}$ & $\begin{array}{l}\text { Initial } \\
\text { Process } \\
\text { Map }\end{array}$ & $\begin{array}{l}\text { Program } \\
\text { Navigator }\end{array}$ & $\begin{array}{l}\text { How many days a week do you work as the } \\
\text { program navigator? }\end{array}$ \\
\hline $\begin{array}{l}\text { CFIR Team } \\
\text { Characteristics }\end{array}$ & $\begin{array}{l}\text { Initial } \\
\text { Process } \\
\text { Map }\end{array}$ & $\begin{array}{l}\text { Program } \\
\text { Navigator }\end{array}$ & $\begin{array}{l}\text { How many navigators are at your site for the } \\
\text { lung screening program? Were there any previous } \\
\text { navigators? If so, how many and how long did } \\
\text { they serve in this role if you know? }\end{array}$ \\
\hline $\begin{array}{l}\text { CFIR Individual } \\
\text { Characteristics }\end{array}$ & $\begin{array}{l}\text { Initial } \\
\text { Process } \\
\text { Map }\end{array}$ & $\begin{array}{l}\text { Program } \\
\text { Navigator }\end{array}$ & $\begin{array}{l}\text { Have you gone through navigator training with } \\
\text { Mt. Sinai? }\end{array}$ \\
\hline $\begin{array}{l}\text { CFIR Process of } \\
\text { Lung Cancer } \\
\text { Screening }\end{array}$ & $\begin{array}{l}\text { Initial } \\
\text { Process } \\
\text { Map }\end{array}$ & $\begin{array}{l}\text { Program } \\
\text { Navigator }\end{array}$ & $\begin{array}{l}\text { Do you currently use the VAPALS-ELCAP } \\
\text { Management System? If so, please provide the } \\
\text { date of the first day you used it? }\end{array}$ \\
\hline $\begin{array}{l}\text { CFIR Process of } \\
\text { Lung Cancer } \\
\text { Screening }\end{array}$ & $\begin{array}{l}\text { Initial } \\
\text { Process } \\
\text { Map }\end{array}$ & $\begin{array}{l}\text { Program } \\
\text { Navigator }\end{array}$ & $\begin{array}{l}\text { Tell me about how Veterans are screened at your } \\
\text { VA (program entry, eligibility verification, rural } \\
\text { outreach, shared decision-making, scheduling } \\
\text { smoking cessation, screening exam ordering, } \\
\text { screening exam visit, type of standardized } \\
\text { screening protocol, follow up on results, work up } \\
\text { of suspicious findings, incidental findings, } \\
\text { annual repeat scan, screening tracking and } \\
\text { management of large panels of patients) }\end{array}$ \\
\hline
\end{tabular}




\begin{tabular}{|c|c|c|c|}
\hline $\begin{array}{l}\text { CFIR Team } \\
\text { Characteristics }\end{array}$ & $\begin{array}{l}\text { Initial \& } \\
\text { Follow Up } \\
\text { Process } \\
\text { Map }\end{array}$ & $\begin{array}{l}\text { Program } \\
\text { Navigator }\end{array}$ & $\begin{array}{l}\text { Please describe who is on your team, specifically } \\
\text { each person's role and specialty. Describe how } \\
\text { you work as a team on a day-to-day basis and } \\
\text { also as a program. }\end{array}$ \\
\hline $\begin{array}{l}\text { CFIR Team } \\
\text { Characteristics }\end{array}$ & $\begin{array}{l}\text { Initial } \\
\text { Process } \\
\text { Map }\end{array}$ & $\begin{array}{l}\text { Program } \\
\text { Navigator }\end{array}$ & $\begin{array}{l}\text { What do you do when you are unsure of } \\
\text { something? How are challenges handled by the } \\
\text { team? }\end{array}$ \\
\hline $\begin{array}{l}\text { CFIR Inner } \\
\text { Setting }\end{array}$ & $\begin{array}{l}\text { Initial \& } \\
\text { Follow Up } \\
\text { Process } \\
\text { Map }\end{array}$ & $\begin{array}{l}\text { Program } \\
\text { Navigator }\end{array}$ & $\begin{array}{l}\text { Do you interact with leaders at your VA besides } \\
\text { your program director? If so, please describe. }\end{array}$ \\
\hline $\begin{array}{l}\text { CFIR Inner } \\
\text { Setting }\end{array}$ & $\begin{array}{l}\text { Initial \& } \\
\text { Follow Up } \\
\text { Process } \\
\text { Map }\end{array}$ & $\begin{array}{l}\text { Program } \\
\text { Navigator }\end{array}$ & $\begin{array}{l}\text { Does your VA provide you with resources to do } \\
\text { your job? If yes, what resources? If no, what } \\
\text { resources would help you do your job? }\end{array}$ \\
\hline FRAME & $\begin{array}{l}\text { Follow Up } \\
\text { Process } \\
\text { Map }\end{array}$ & $\begin{array}{l}\text { Program } \\
\text { Navigator }\end{array}$ & When and how were modifications made? \\
\hline FRAME & $\begin{array}{l}\text { Follow Up } \\
\text { Process } \\
\text { Map }\end{array}$ & $\begin{array}{l}\text { Program } \\
\text { Navigator }\end{array}$ & $\begin{array}{l}\text { Were these changes planned and proactive (e.g., } \\
\text { intentional adaptation) or unplanned and } \\
\text { reactive (e.g., in response to other forces)? }\end{array}$ \\
\hline FRAME & $\begin{array}{l}\text { Follow Up } \\
\text { Process } \\
\text { Map }\end{array}$ & $\begin{array}{l}\text { Program } \\
\text { Navigator }\end{array}$ & Who decided changes were necessary? \\
\hline FRAME & $\begin{array}{l}\text { Follow Up } \\
\text { Process } \\
\text { Map }\end{array}$ & $\begin{array}{l}\text { Program } \\
\text { Navigator }\end{array}$ & What was modified? \\
\hline FRAME & $\begin{array}{l}\text { Follow Up } \\
\text { Process } \\
\text { Map }\end{array}$ & $\begin{array}{l}\text { Program } \\
\text { Navigator }\end{array}$ & $\begin{array}{l}\text { At what level in the system were changes made } \\
\text { (executive leadership, department/service line } \\
\text { leadership, healthcare provider, or staff level)? }\end{array}$ \\
\hline FRAME & $\begin{array}{l}\text { Follow Up } \\
\text { Process } \\
\text { Map }\end{array}$ & $\begin{array}{l}\text { Program } \\
\text { Navigator }\end{array}$ & $\begin{array}{l}\text { What were the reasons modifications were made } \\
\text { and what other factors were at play? }\end{array}$ \\
\hline
\end{tabular}

*Domains are based on the Reach, Effectiveness, Adoption, Implementation, and Maintenance (RE-AIM) Framework, the Consolidated Framework for Implementation Research (CFIR), and the Framework for Reporting Adaptations and Modifications to Evidence-based Interventions (FRAME) frameworks ${ }^{38,40,46}$

\section{Figures}




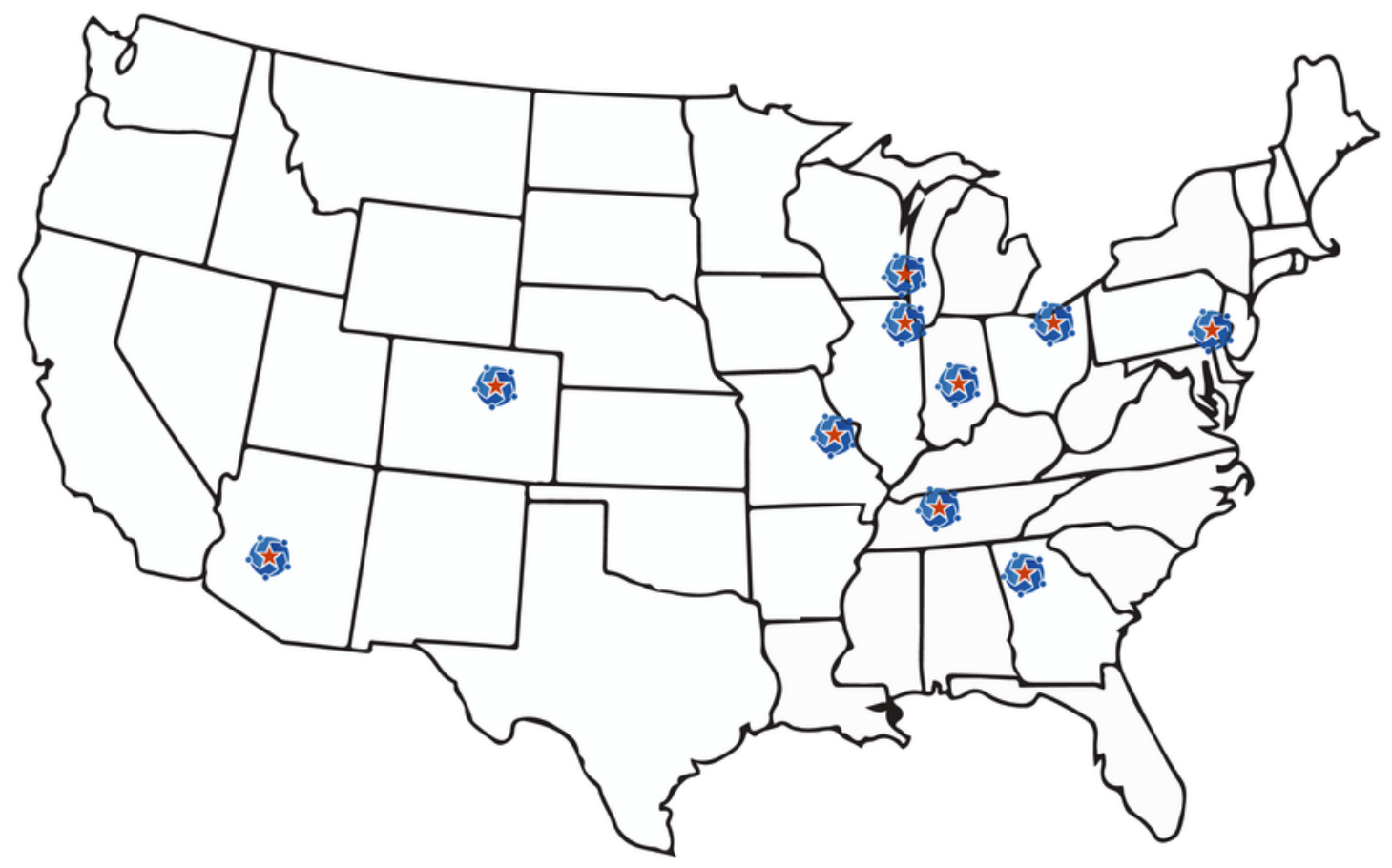

VA-PALS SITES:

Atlanta | Chicago | Cleveland | Denver I Indianapolis | Milwaukee | Nashville | Philadelphia | Phoenix | St. Louis

Figure 1

VA-PALS SITES 


\begin{tabular}{|c|c|c|c|c|}
\hline$\pm \perp$ INPUTS & 品二 & STIVITIES & & JTCOMES \\
\hline $\begin{array}{l}\text { PEOPLE } \\
\text { - leadership Team } \\
\text { - Soffware Team } \\
\text { - Program Evaluation Team } \\
\text { - local Teams } \\
\text { - Champions } \\
\text { - Navigators } \\
\text { - Providers } \\
\text { - Staff } \\
\text { - Leadership } \\
\text { TECHNOLOGY } \\
\text { • ELCAP Management System } \\
\text { - CT Scanners } \\
\text { - CT Phantoms }\end{array}$ & $\begin{array}{l}\text { SUPPORT NETWORK } \\
\text { - Weekly leadership Calls } \\
\text { - Monthly Navigator Roundiable Calls } \\
\text { - Program Director Calls } \\
\text { - Writinen Guide to lung Screening } \\
\text { - Availability to Answer Questions } \\
\text { - Website \& Shared Resources } \\
\text { QUALITY ASSURANCE } \\
\text { - CT Phantoms and Feedback } \\
\text { - VAPALS-ELCAP Management System } \\
\text { TRAINING } \\
\text { - Navigator \& Radiologist Training }\end{array}$ & $\begin{array}{l}\text { CLINICAL LUNG SCREENING } \\
\text { • Recruitment } \\
\text { - Shared Decision Making } \\
\text { - Smoking Cessation } \\
\text { - LDCT Screening } \\
\text { Downstream Follow-up } \\
\text { DATA COLLECTION } \\
\text { - VAPALS-ELCAP Management System } \\
\text { - VA Corporate Data Warehouse } \\
\text { - Surveys } \\
\text { - In-depth Interviews }\end{array}$ & $\begin{array}{c}\leq 24 \text { MONTHS } \\
\text { REACH } \\
\text { EFFECTIVENESS } \\
\text { ADOPTION } \\
\text { IMPLEMENTATION }\end{array}$ & $\begin{array}{c}\text { REACH } \\
\text { EFFECTIVENESS } \\
\text { IMPLEMENTATION } \\
\text { MAINTENANCE }\end{array}$ \\
\hline
\end{tabular}

Figure 2

Logic Model 


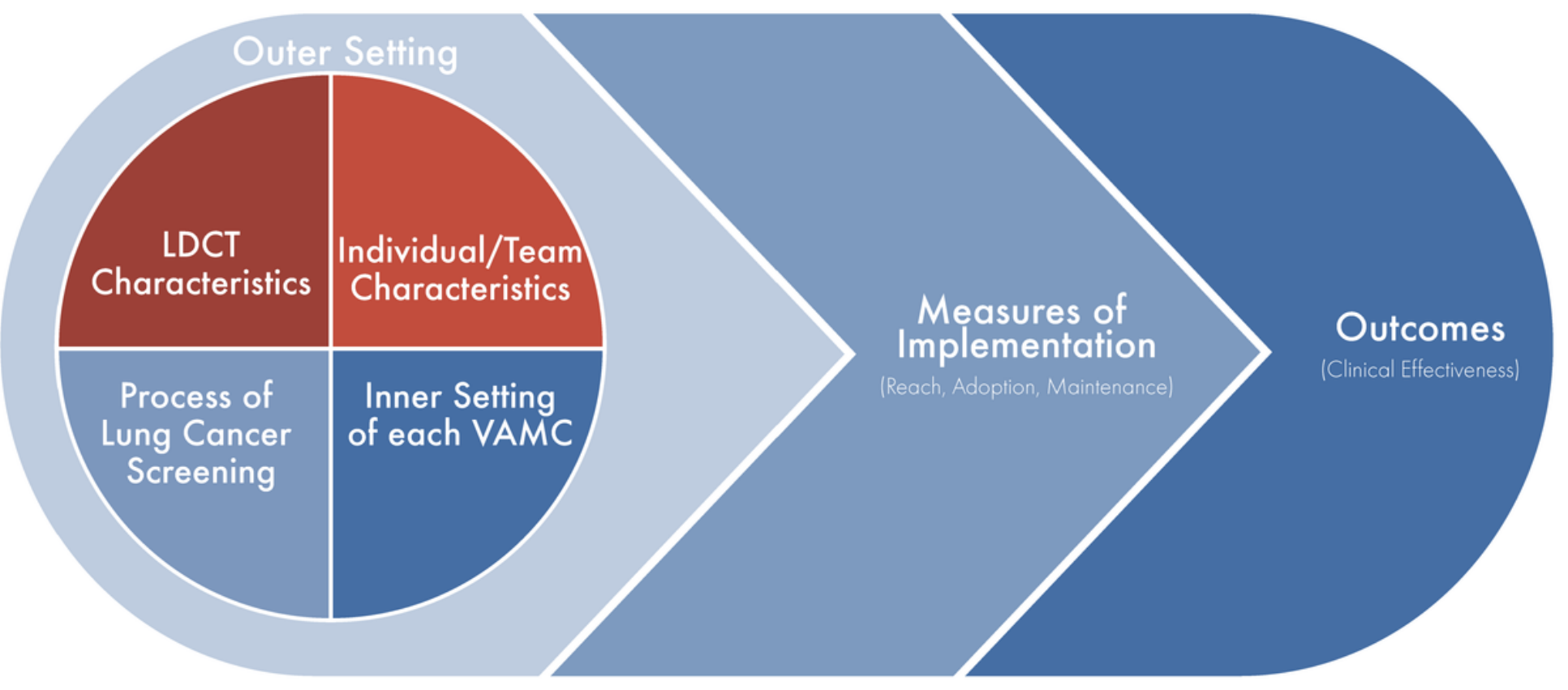

Figure 3

Thoroughly exploring each of these domains will inform future implementation strategies 


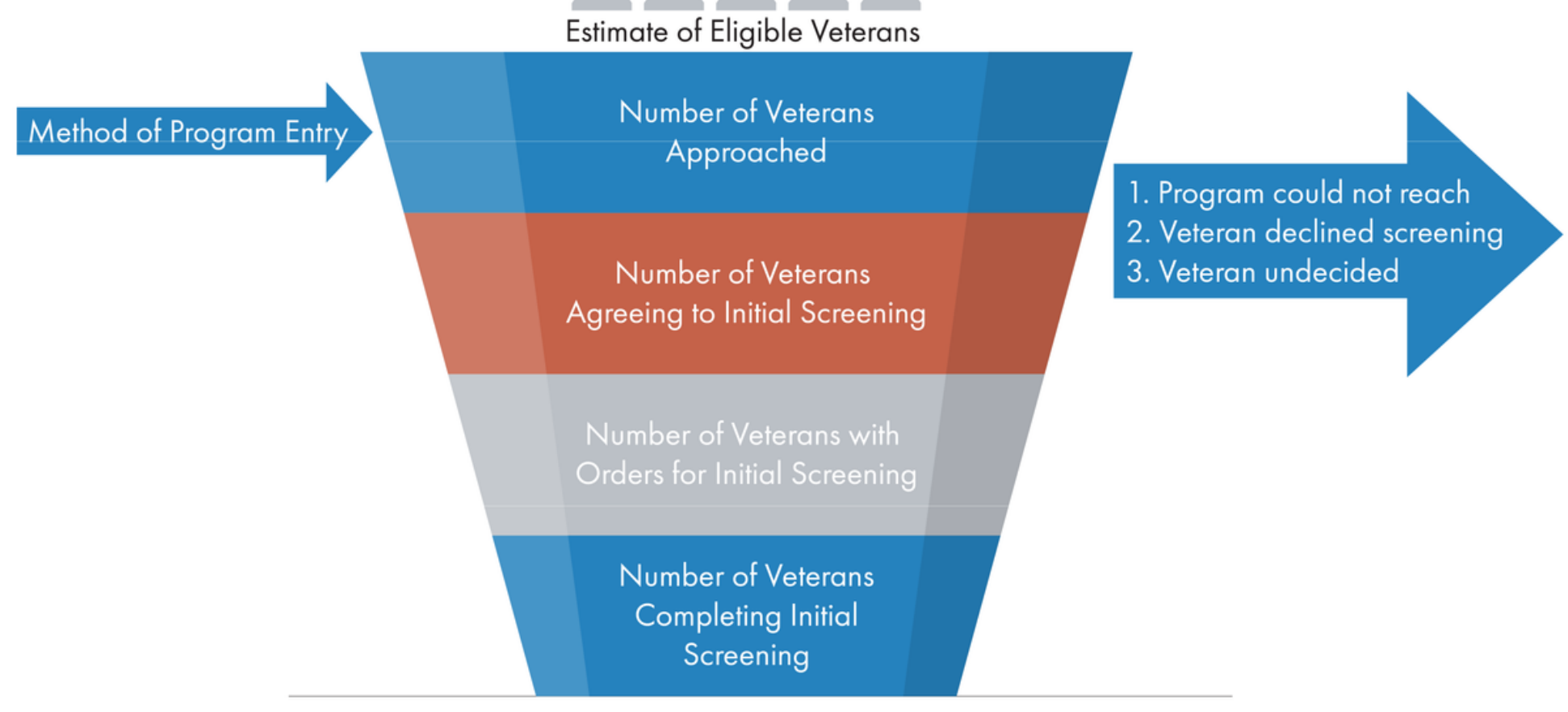

Figure 4

unique Veterans completing initial screens 